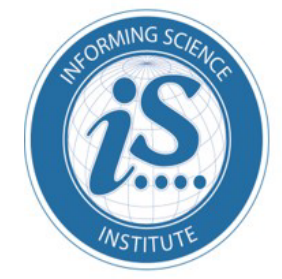

Interdisciplinary Journal of Information, Knowledge, and Management

An Official Publication

of the Informing Science Institute

InformingScience.org

IJIKM.org

Volume 13, 2018

\title{
The Role of Knowledge Management Process AND INTELLECTUAL CAPITAL AS INTERMEDIARY VARIABLES BETWEEN KNOWLEDGE MANAGEMENT INFRASTRUCTURE AND ORGANIZATION PERFORMANCE
}

Shadi Abualoush

Ra'ed Masa'deh*

Khaled Bataineh

Ala'aldin Alrowwad

* Corresponding author
Irbid National University, Irbid, Jordan

The University of Jordan, Amman, Jordan

Irbid National University, Irbid, Jordan

The University of Jordan, Aqaba Branch, Jordan shadi habes@inu.edu.jo

r.masadeh@ju.edu.jo

dr.khaled.adnan@inu.edu.jo

a.alrowwad@ju.edu.jo

ABSTRACT

Aim/Purpose The objective of this study was to assess the interrelationships among knowledge management infrastructure, knowledge management process, intellectual capital, and organization performance.

Background

Although knowledge management capability is extensively used by organizations, reaching their maximum financial and non-financial performances has not been fully researched. Therefore, organizations need to optimize their performance by exploiting knowledge management capability through the accumulation of intellectual capital, where the new competitiveness is shifting from tangible to intangible resources.

Methodology This study adopted a positivist philosophy and deductive approach to accomplish the main goal of this research. Moreover, this research employed a quantitative approach since this study is concerned with causal relationship between variables. A questionnaire-based survey was designed to evaluate the research model using a convenience sample of 134 employees from the food industry sector in Jordan. Surveyed data was examined following the structural equation modeling procedures.

Accepted by Editor Jon Webber | Received: April 3, 2018 | Revised: June 9, June 16, June 25, 2018 |

Accepted: July 3, 2018.

Cite as: Abualoush, S., Masa'deh, R., Bataineh, K., \&Alrowwad, A. (2018). The role of knowledge management process and intellectual capital as intermediary variables between knowledge management infrastructure and organization performance. Interdisciplinary Journal of Information, Knowledge, and Management, 13, 279-309. https://doi.org/10.28945/4088

(CC BY-NC 4.0) This article is licensed to you under a Creative Commons Attribution-NonCommercial 4.0 International License. When you copy and redistribute this paper in full or in part, you need to provide proper attribution to it to ensure that others can later locate this work (and to ensure that others do not accuse you of plagiarism). You may (and we encourage you to) adapt, remix, transform, and build upon the material for any non-commercial purposes. This license does not permit you to use this material for commercial purposes. 
Contribution

Findings

Recommendations for Practitioners

Recommendations for Researchers

Impact on Society

Future Research

Keywords
This study highlighted the potential benefits of applying the knowledge management capabilities, intellectual capital, and organizational performance to the food industrial sector in Jordan. Future research suggestions are also provided.

Results indicated that knowledge management infrastructure had a positive effect on knowledge management process. In addition, knowledge management process impacted positively intellectual capital and organization performance and mediated the relationship between knowledge management infrastructure and intellectual capital. However, knowledge management infrastructure did not positively associate to organization performance.

The current model is designed to help managers and decision makers to improve their management capabilities as well as their organization financial and non-financial performance through exploiting the organizational knowledge management infrastructure and intellectual capital approaches.

Our findings can be used as a base of knowledge to conduct further studies about knowledge management capabilities, intellectual capital, and organization performance following different criteria and research procedures.

The designed model highlights a significant organizational performance approach that can influence Jordanian food industrial sector positively.

The current designed research model can be applied and assessed further in other sectors including banking and industrial sectors across developed and developing countries. Also, we suggest that in addition to focusing on knowledge management process and intellectual capital as mediating variables, future research could test our findings in a longitudinal study and examine how to affect financial and non-financial performance.

knowledge management infrastructure, knowledge management process, intellectual capital, organization performance, Jordan

\section{INTRODUCTION}

Due to the complexity of business environment and competition intensity, organizations realized that the value of intangible assets is a critical determinant for organization's competitiveness (Abualloush, Bataineh, \& Aladwan, 2017; Chien, Yuan, \& Hsiung, 2015; Hussinki, Ritala, Vanhala, \& Kianto, 2017). Intellectual capital is a source of creativity and innovation and one of the main factors for organizations' success, especially as it is the initiator and catalyst for development and achievement. This requires organizations wishing to obtain a competitive advantage to attract intellectual capital and work to develop and maintain it in a way that distinguishes it from competitors to ensure its survival and continuity (Luiza, 2016). Scholars argued that organizations must be creative and superior in their ideas to achieve the desired excellence through intellectual capital and provide effective solutions to current and future problems (Chien et al., 2015; Obeidat, Tarhini, Masa'deh, \& Aqqad, 2017). In fact, organizations must understand business processes, adopt new strategies to economic openness, manage the requirements of the information revolution through the adoption of practical methods and practices, concentrate on intellectual capital through its polarization, develop and sustain in order to possess intangible resources (including tacit knowledge embedded in the minds of their human resources), and add value or market share greater than its competitors (Luiza, 2016).

Recently, technology has become increasingly important worldwide. Consequently, the role of knowledge as a core unit of wealth has depended on creative capabilities, expertise, and skills of individuals to generate new knowledge. The generated knowledge and its interaction with the human element (represented by human experience), values, beliefs, and skills is now one of the most effective, influential, and adopted elements in management process across the organization (Jyoti \& Rani 
2017; Lee, Florida, \& Gates, 2010; Maruf \& Zhou, 2015). Knowledge is viewed as the key strategic resource for organizational survival, stability, growth, and improvement (Al-Ali, 2013; Sweis, Fallaq, Buqjati, \& Abu-Hammad, 2011). Knowledge management can assist organizations to remain competitive, through sharing information with the external partners and knowing their competitors' products, services, strategies, and best practices (Attia \& Salama, 2018). In addition, knowledge management can help organizations in acquiring, interpreting, and using knowledge related resources across functional boundaries to create the new knowledge (Gharakhani \& Mousakhani, 2012; Hussinki et al., 2017).

Moreover, "Organizational performance refers to the ability of organizations to meet its stakeholder's needs and its own needs for survival" (Obeidat, 2016, p. 367). Organizations strive to improve effective strategies that explore opportunities in the market through their ability to make use of their available resources (Cania, 2014). To achieve this goal, organizations' performance does not depend only on the tangible resources available in the organization, but also on intangible resources such as effective knowledge management and the development of intellectual capital (Richard, Devinney, \& Yip, 2008). The success of the organization is related also to their ability to explore and develop new knowledge to be used in innovation and in achieving their goals (Allameh, Zare, \& Davoodi, 2010).

Many studies have shown the relationship between intellectual capital and knowledge management and their impact on organization performance (Hsu \& Sabherwal, 2011; Mehralian, Nazari, Akhavan, \& Rasekh, 2014; Mikkawi, Masa'deh, \& Al-Lozi, 2017); however, those studies overlooked the role played by knowledge management infrastructure in supporting and developing knowledge management processes and the accumulation of intellectual capital (Ramadan, Dahiyat, Bontis, \& Aldalahmeh, 2017). Therefore, the main goals of this study were to (1) examine the relationship between the knowledge resources in the organization that were represented in knowledge management process (generation, sharing, storage, application of knowledge) and intellectual capital (human capital, structural capital, relational capital) and to (2) test the role of knowledge management infrastructure as instrumental and enabling factors in the organization's knowledge resources, knowledge management, and intellectual capital in the food industry in Jordan. To achieve those goals, this study attempts to answer the following questions:

-Does knowledge management infrastructure impact the knowledge management processes?

- Does knowledge management infrastructure impact organization performance?

- Do knowledge management processes impact organization performance?

- Do knowledge management processes impact intellectual capital?

- Does intellectual capital impact organization performance?

This paper is organized as follows. It begins with the relevant literature and previous studies about knowledge management processes, infrastructure, intellectual capital, and organizational performance. Then, theoretical framework and hypotheses development are presented. Next, it explains the research methodology. After that, the research findings are presented. Finally, research discussions, implications, limitations, and future research directions are presented.

\section{LITERATURE REVIEW}

\section{KNOWLEDGE MANAGEMENT INFRASTRUCTURE (KI)}

Knowledge management infrastructure is considered a perquisite to reinforce knowledge management processes inside an organization (Abed Al-Qader, 2014; Allameh et al., 2010; Bishop, Bouchlaghem, Glass, \& Matsumoto, 2008). It represents the long-term basis for knowledge and information management in the organization (Fernandez \& Sabherwal, 2010; Pannu, 2017). Knowledge management infrastructure is defined as the mechanisms for the development of knowledge within the organization that stimulate the process of creating and generating knowledge (Zaied, Hussein, \& Hassan, 2012). Imran (2014) defined knowledge management infrastructure as the organization's en- 
vironment by which knowledge is acquired, retrieved, applied, protected, and stored in order to become easy to use. Kushwaha \& Rao (2015) concluded that knowledge management infrastructure contains two main elements: technical infrastructure and social infrastructure. They suggested that the technical infrastructure includes information technology infrastructures, tools, and hardware, while the social infrastructure includes organizational culture, organization structure, and human resources. Additionally, Fernandez \& Sabherwal (2010) suggested five main elements for knowledge management infrastructure: (1) the common knowledge, (2) organization structure, (3) information technology infrastructure, (4) organizational culture, and (5) physical environment. However, the key components of knowledge management infrastructure are common knowledge, physical space, human resources management procedures, IT, and organizational structure (Sytnik, 2016). Also, knowledge management infrastructure's main component might include information technology, organization structure, and organizational culture (Gold, Malhotra, \& Segars, 2001). The common knowledge management infrastructure factors that have been evaluated across the previous studies included Organizational Culture (OC), IT Infrastructure (IT), and Organizational Structure (OS).

\section{Organizational Culture (OC)}

Organizational culture is defined as the rules and behavior that guide the behavior of the staff of the organization (Fernandez \& Sabherwal, 2010; Theriou, Maditinos, \& Theriou, 2011). It is referred to as assumptions established within the organization and approved by its members that are discovered or developed through learning to deal with problems and to teach new employees the patterns of problem-solving correctly (Pannu, 2017). Organizational culture is also known as a set of assumptions, rules, standards, systems, and beliefs shared by employees within the organization that affect their thinking and decision-making (Obeidat, Al-dalahmeh, \& Masa'deh, 2015). Organizational culture comprises the norm which provides guidance to people's attitude as well as behavior in an organization. Organizational culture is thus highly significant as it greatly affects the success requirements. These requirements include customer service, efficiency, innovation, product reliability, and quality. It is hence necessary to have the knowledge on how organizational culture facilitates the processes of knowledge management (Sun, 2010). The organizational culture is considered to be a vital factor in building and reinforcing knowledge management in organizations as it impacts how employee learn, acquire, and share knowledge (Rai, 2011).

\section{IT Infrastructure (IT)}

Researchers and analysts agree that IT infrastructure is most important in knowledge management. It is seen as a crucial factor in making knowledge management processes more efficient, in terms of supporting and facilitating knowledge generation, storage, transmission, sharing, and application (Gold et al., 2001). IT infrastructure includes various hardware and software that facilitate and help in providing technological capabilities that lead to transfer of knowledge from one unit to another and contribute to the retrieval of relevant information and data when needed (Jaradat \& Al Maani, 2014). Information technology works to facilitate user access to the knowledge required and increases communications between users, especially experts. The tools provide assistance in group activities and projects; IT also has the ability to store, preserve, and retrieve knowledge through the use of knowledge management databases (George, 2014).

\section{Organizational Structure (OS)}

Knowledge management depends significantly on organizational structure. Gold et al. (2001) defined organizational structure as formal allocation of work tasks, roles, responsibilities, and authorities that exist within an organization, including policies, procedures, hierarchic relationships, and sector boundaries. Organization structure is the allocation and division of functions, the development of systems procedures, and the definition of authority (Cortés, Zaragoza-Sáez, \& Ortega, 2007). Additionally, organizational structure is seen as a component framework of functions that are able to direct the behavior of individuals and groups towards achieving the goals of the organization (Cortés 
et al., 2007). It refers to the extent to which the organization is structured to promote knowledgerelated activities (Zaied et al., 2012). Organizational structure includes two dimensions: centralization, which refers to the degree of authority and control of decisions within the organization; and formalization, which refers to the formal rules, procedures, and policies governing the working relationship and decisions (Masa'deh, Obeidat, \& Tarhini, 2016).

\section{KNOWLEDGE MANAGEMENT PROCESS (KP)}

Knowledge is considered one of the most valuable assets in modern organizations. Initially, Drucker (1994) indicates that the world is already dealing with knowledge industries whose ideas are that products, data, and raw materials, and the human mind became its tool. Knowledge becomes a real wealth for both individuals and organizations. It is the vital and effective tool through which organizations are able to fulfill their tasks and carry out their activities in order to achieve their goals efficiently. Further, knowledge generates innovations and transforms them into products and processes (Maruf \& Zhou, 2015). Knowledge management (KM) may simply be defined as "doing what is needed to get the most out of knowledge resources" (Fernandez \& Sabherwal, 2010). Hajir, Obeidat, Al-dalahmeh, \& Masa'deh (2015) defined KM as the transfer of appropriate knowledge to the right person at the right time to help individuals to share information and improve the organization and its effectiveness, in addition to adopting modern methods that develop the abilities of individuals to create and innovate. It has a critical aspect of production in addition to human resources and capital. It is also a source of excellence for organizations and the basis for their advancement and success (Obeidat, Al-Suradi, Masa'deh, \& Tarhini, 2016).

In addition, Obeid \& Rabay'a (2016) defined KM as the processes that help the organization to gain, organize, generate, and disseminate knowledge, as well as to transfer important information and expertise that the organization possesses to various management activities, such as decision making, problem solving, learning, and strategic planning. Knowledge management is also defined as the processes and activities that assist the organization in generating, acquiring, discovering, and organizing knowledge and in using and disseminating it among the working people, and transferring information and experiences that the organization has and applying them in its management activities, such as decision making, job procedures, and strategic planning (Hussinki et al., 2017).

\section{Knowledge Generation (KG)}

Knowledge generation is represented within the all procedures that an organization seeks through it to produce and get knowledge be it explicit or tacit knowledge (Obeid \& Rabay'a, 2016). Knowledge generation is the interaction between explicit and tacit knowledge, which result into new knowledge (Kasasbeh, 2015). Knowledge generation involves the developing of new knowledge or the replacement of existing content of the organization's tacit and explicit knowledge. Through social and collaborative processes, as well as individuals' cognitive processes, knowledge is created, shared, amplified, enlarged, and justified in organizational settings (Chang \& Lin, 2015). Nonaka \& Takeuchi's model, mutual conversion of tacit and explicit knowledge is a four-dimensional process. They are namely; "Socialization, Conversion of tacit knowledge into a new tacit knowledge such as sharing the experiences among organization's members; Externalization, Transfer of tacit knowledge into a new explicit knowledge such as documentation of best experiences; Combination, Conversion of explicit knowledge into a new explicit knowledge such as assessing papers and reports in the same sector; Internalization, Conversion of explicit knowledge into a new tacit knowledge like learning from written collective discussions" (Nonaka, Toyama, \& Konno, 2000, p. 9-10).

\section{Knowledge Storage (KS)}

Generating and acquiring new knowledge is not sufficient for decision making purposes. Mechanisms are needed to store it and to retrieve it when needed. Knowledge storage means "storing existing, acquired, and created knowledge in properly indexed and inter-linked knowledge repositories" 
(Ranjbarfard et al., 2014, p. 512). Knowledge storage refers to maintaining and managing knowledge continuously in organizational memory and knowledge bases. This requires constantly updating organizational memory and improving communication tools to facilitate access by employees (Al-Ali, 2013). This process also includes all activities that allow knowledge to be stored, updated, and easily retrieved by users (Al-Shanti, 2017). Organizations must store and structure knowledge, thereby making it more accessible and distributable. By combining or integrating knowledge and reducing the redundancy, the efficiency could be improved (Chang \& Lin, 2015).

\section{Knowledge Sharing (KR)}

The process of knowledge sharing is an important component of the success of knowledge management. It is also crucial for the proper utilization and use of knowledge assets. KR also directly impacts other knowledge processes, such as knowledge integration and creation (Masa'deh et al., 2016). The process of knowledge sharing helps people exchange tacit and explicit knowledge and generate new knowledge among the target people (Birasnav, 2014). Knowledge sharing can be defined as the particular process of the organization used to disseminate, transfer, and exchange knowledge among employees. In addition, it is the basis for creating and generating new knowledge (Bouraghda \& Dris, 2015). Knowledge sharing refers to the process whereby individuals share experiences and information with each other, and thus increasing the organization's resources and reducing time loss in trial and error (Dalkir, 2005).

\section{Knowledge Application (KA)}

Utilization of knowledge effectively ensures that the organization's goals are achieved efficiently and effectively with the delegation of powers and freedom through the organization (Bouraghda \& Dris, 2015). Knowledge application intends to make the activities of the organization more appropriate for use. The knowledge application is the aim of managing knowledge, and it means investing in knowledge - getting it stored and shared are not enough. The purpose of knowledge application is to transform the knowledge into practical application. The success of any knowledge management program in the organization depends on the amount of applied knowledge (Dalkir, 2005). Knowledge should be used by the organization to solve the problems that arise inside the firm. "The effective application of knowledge is the cornerstone of organizational innovation, as innovation is essentially seen as the process through which the organization follows a set of activities designed to enable it to utilize and apply created and learned knowledge to: develop new products/services, managerial systems, technologies, and processes; solve new problems; improve overall performance and productivity; and modify any aspects of its business" (Dahiyat, 2015, p. 118).

\section{INTELLECTUAL CAPITAL (IC)}

Intellectual capital, in the current economic environment, is one of the most important topics for researchers, practitioners, and stakeholders. It is seen as the essence of the administrative process due to the fact that it plays a key role in all administrative aspects to make management more vital and effective (Sangiorgi \& Siboni, 2017). It is also built primarily on human knowledge, human creativity, expertise, and valuable skills (Tastan \& Davoudi, 2015). Stewart (1997) gives a comprehensive definition of intellectual capital as the combination of knowledge, information, intellectual assets, and experience possessed by each individual in an organization that may be used to create wealth and competitive advantage.

The present study focuses on three main elements of intellectual capital, including human, structural, and relational aspects of intellectual capital, that were mentioned by many researchers in their studies(Bontis, 1998; Mehralian et al., 2014; Pour, Masjedi, \& Akhavan, 2015; Rehman \& Abdul Rehman, 2015; Tastan \& Davoudi, 2015; Wang, Wang, \& Liang, 2014). 


\section{Human Capital (HC)}

Human capital is considered to be the most important component of intellectual capital because the whole organization depends on it; Obeidat et al. (2017) stated that the human capital is extremely vital to organizations as employee capabilities are reflected on the performance of the firm. It is very important to organizations due to its role as source for innovation and strategic change (Rehman \& Abdul Rehman, 2015; Obeidat et al., 2017). It is the sum of staff competence, knowledge, experience, experiments, attitude, commitment, and wisdom that represents the organization's individual knowledge base to reach specific goals (Wang et al., 2014). It is also referred to as professional expertise, abilities, and knowledge of employees to enhance organizations' performance for competitive advantage (Rehman \& Abdul Rehman, 2015).

\section{Structural Capital (SC)}

Structural capital is defined as the strategic asset value of organizational capacity, routine business, patents, trademarks, intellectual property rights, databases, hardware and software, information systems, organizational culture, organization image, and procedures (Seleim, Ashour, \&Bontis, 2007). Structural capital "is the glue of the organization. It is based on the internal structure of the organization, and its processes and procedures, guidelines, and rules, etc. It is the aggregate of all knowledge in organizations including organizational competitive intelligence, routine, formula, policies, procedures, and databases" (Sivalogathasan \& Wu, 2015, p. 154). Structural capital contains all the non-human storehouses of knowledge, such as systems, databases, networks, process manuals, procedures, and routines (Bontis, 1998; Khalique, Shaari, \& Isa, 2011).

\section{Relational Capital (RC)}

Relational capital refers to strategic alliances with internal and external stakeholders (suppliers, customers, employees) or relational capital is formed by the knowledge embedded in the relationships with the external environment (Pirozzi \& Ferulano, 2016; Rehman \& Abdul Rehman, 2015). It also refers to customer satisfaction or end user loyalty to the organization (Yaghoubi, Salarzehi, \& Moloudi, 2010). Relational capital refers to the knowledge embedded in the relationships with customers based on brand value, a strong network of customers, customer loyalty, and customer satisfaction (Bontis, 1998). Relational Capital "comprises alliances, relationship with different stakeholders (such as customers, partners, suppliers, investors and so on) as well as franchises, trademarks, licenses, distribution networks, government bodies and agencies, image and brand, communities, public and environment"(Hejase, Hejase, Tabsh \& Chalak, 2016, p. 579).

\section{ORGANIZATION PERFORMANCE (OP)}

Organizational performance is one of the most studied topics in administrative research and business (Gavrea, Ilieş, \& Stegerean, 2011). It is a vital issue for all profit making and non-profit organizations. Also, organizational performance is the most important criterion in assessing organizations, their actions, and their environments. Improving organizational performance is a prerequisite for strategic management of the organization that seek maximum performance (Cania, 2014). Performance is a comprehensive concept for all activities in organizations of all types. Organizational performance is defined as a quality of work, efficiency of staff in decision making, improvement and development of processes, staff relationship with their leaders, diversity of services and products, innovations, market share, staff skills and experience in problem solving, new methods and modern techniques of product development (Imran, 2014). Organizational performance is also referred to as the degree by which the organization meets its own needs and the needs of stakeholders to survive and grow (Pandey \& Dutta, 2013).

Organizational performance is the ability of the organization to access and handle various organizational resources in order to achieve its goals and objectives (Sangiorgi \& Siboni, 2017). There is an agreement among researchers that a performance measurement system is vital for organizations be- 
cause it provides information on the quality of their operations within organizations, it helps in the development of strategic plans, and it evaluates the achievement of organizational goals (Alrowwad, Obeidat, Tarhini, \& Aqqad, 2017). Studies presented in the Jordanian business environment focused on measuring the performance of organizations on two main dimensions: (1) financial performance and (2) operational performance (Al-Ti, 2016; Alrowwad et al., 2017; Obeidat et al., 2017; Zeglat \& Zigan, 2014). Both dimensions were used in this study to measure organization performance.

\section{Financial Performance (FP)}

Traditionally, performance measurement has been strongly influenced by financial reporting, which leads to the development of many financial metrics. Financial performance is referred to as the achievement of economic objectives reflected in the results of financial and market indicators (Tomislav, Bach, \& Vukšić, 2012). Also, financial performance refers to a measure of the change of the financial state of an organization, or the financial outcomes that result from management decisions and the execution of those decisions by members of the organization (Carton, 2004). In fact, most of the financial indicators used include profit margins, return on asset, return on equity, growth, costs, return on investment, and sales growth (Alrawabdeh, 2014; Alrowwad et al., 2017; Tomislav et al., 2012).

\section{Non-Financial Performance (NP)}

Non-financial performance measures are non-financial aspects of the organization, such as product quality, customer satisfaction, delivery on time, efficiency, productivity, market share, employee satisfaction, strategic goal attainment, workforce development and improvement (Richard et al., 2008). The main advantage of non-financial performance measurement is its positive impact on the future financial performance (Tomislav et al., 2012). Additionally, non-financial performance measures are widely used to transfer the organization's strategy and vision to influence the organizational performance and thus affect the future performance of the organization (Obeidat et al., 2017).

\section{THEORY MODEL AND HYPOTHESES}

\section{RESEARCH MODEL}

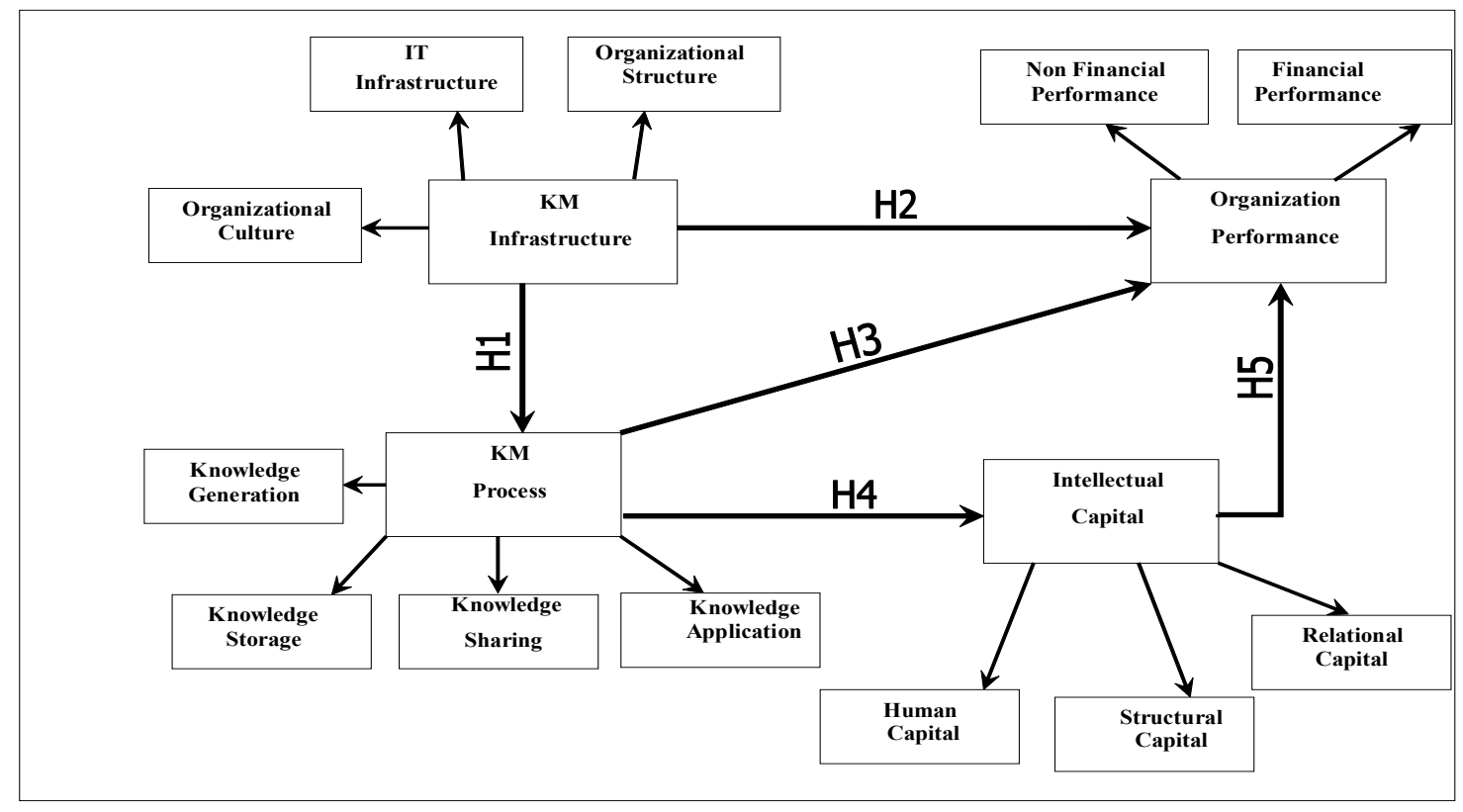

Figure 1. Research model 
Based on the literature review, our theory model, as presented in Figure 1, considers the interrelationships among Knowledge Management Infrastructure (KI), Knowledge Management Process (KP), Intellectual Capital (IC), and Organization Performance (OP). We discuss the theory model for developing research hypotheses in the following subsections.

\section{Knowledge Management Infrastructure and Knowledge Management Process}

Knowledge Management Infrastructure is the foundation of knowledge in the form of processes that help the organization to generate, create, acquire, test, organize, use, and disseminate knowledge as well as transform the expertise of the organization into important knowledge for administrative activities, such as decision making, strategic planning, learning, and problem solving (Kushwaha \& Rao, 2015). The organizational culture enhances knowledge management, encourages its creation and generation, and facilitates its sharing and application among employees. It fosters the environment for free flow of ideas. It is also the key of the organizations' ability to manage knowledge in the proper approach (Chang \& Lin, 2015; Valaei, Nikhashemi, \& Javan, 2017). Another vital role of the organization's culture in the management of knowledge is based on the existence of a positive and supportive culture towards knowledge in terms of its productivity, participation, and establishment of a society based on knowledge sharing as well as effective networking in interpersonal relations (Sytnik, 2016).

Certainly, the success of the knowledge system, determined by the existence of an organizational culture that supports the efforts and activities of the employees to build and develop the knowledge, can be used to improve the work performance (George, 2014). Culture translates the work behavior of employees, organizational vision, and work environment; besides, the organizational culture of collaboration in the work atmosphere will positively affect knowledge creation and improve its exchange practices (Meihami \& Meihami, 2014).

The success of knowledge management depends broadly on the necessity for a flexible and capable organizational structure responding to changes in and outside the organization (Abed Al-Qader, 2014). The organization's structural types and characteristics affect the embedded processes of creating, transforming, and sharing of knowledge by impacting the "social interaction" patterns within the organization (Acharya \& Mishra, 2017). Flexible, flat, and decentralized organizational structures are the most appropriate in the field of knowledge management. They can facilitate knowledge management processes through practice communities and provide access to external knowledge sources from social networks (Mikkawi et al., 2017).

IT infrastructure is one of the most important knowledge management enablers within every organization. It is very clear that the internal networks, databases, intranet, and social networking platforms are the main parts and supporters of the knowledge management. These IT important items facilitate rapid access to information, communication, and collaboration among personnel in the organization (Imran, 2014; López, Peón, \& Ordás, 2009). All knowledge management systems require a certain level of technology and infrastructure support to be effective. Thus, IT plays a main role in enabling and facilitating the interaction between the employees to implement the process of KM and determines how the knowledge travels throughout the enterprise (Alzou'bi \& Al-Zaidy, 2012; Hajir et al., 2015; Valaei \& Rezaei, 2017). Based on that, we propose the following hypothesis:

H1: There is a positive effect of Knowledge Management Infrastructure on Knowledge Management Process.

\section{Knowledge Management Infrastructure and Organization Performance}

It is possible to study the influence of Knowledge Management Infrastructure (KMI) on organization performance. KM infrastructure is the environment of the organization through which knowledge creation, knowledge sharing, knowledge application, knowledge protection, and knowledge storage becomes easy, and it is the best enabler for organizations to perform the KM sys- 
tems, framework, and capabilities quite easily, effectively and efficiency (Obeidat et al., 2017). Organization culture forms a core and parent element of the organization because its urges employees to generate, acquire, and share knowledge; this is indictor of an active KMI and enhances KM, which reflects organized performance (Alrowwad et al., 2017). The competitive advantage and the outstanding performance can be realized only through knowledge management; culture determines the value of knowledge in providing a competitive advantage for an organization. To promote KM, a collaborative climate where employees support and help each other in their tasks has to be fostered (Tan \&Wong, 2015). Moreover, organizations that have a wider social relationships network and collaborative culture will have a better performance, particularly since they work on increasing the effectiveness of knowledge management, which in turn promotes the socialization and internalization process (Imran, 2014).

Information technology helps the organization in conveying the organizational objectives to the organizations' staff in a timely manner (Imran, 2014). Zaied et al. (2012) indicated that the organizations that have a developed and advanced information technology own a competitive advantage better than that of competitors. Technology occupies a fundamental place within the integrated framework of knowledge management, because it works on generating new knowledge and storing the same in the existing knowledge repository, and for facilitating the knowledge recovery and protecting the same from misuse (Imran, 2014).

Many researchers referred to the organizations' need to change their hierarchical organizational structure to the flatter structure and network style. The fewer administrative levels, as in the flatter pattern, the easier are the processes of knowledge generation, sharing, and conveying. Further, the flatter structure provides easy communication between individuals and departments inside the organization and free flow of ideas among employees, because it increases the empowerment degree for the employees and participation in decision making creativity (Beveren, 2003; Yadav, 2013). The most successful organizations in the future will be the ones characterized by the flexibility and simplicity of the organizational structure (Laudon \& Laudon, 2014). Based on these arguments, it is hypothesized that:

H2: There is a positive effect of Knowledge Management Infrastructure on Organization Performance.

\section{Knowledge Management Process and Organization Performance}

Measuring the effectiveness of knowledge management and its contribution to the organizational performance is a major challenge to many organizations, which determines the effectiveness of knowledge management in terms of the beneficial results gained from of knowledge management (Tubigi \& Alshawi, 2015). The company's knowledge base is usually considered as the main factor embedded in the performance levels (Yadav, 2013). Knowledge resources have captured the interest of the organizations for being one of the most important resources in strategic terms for the organization (Masa'deh, 2016). This is due to its positive impact on acquiring a competitive advantage and on innovation improvement, which leads the organization to outstanding performance (Bouraghda \& Dris, 2015; Pension, Nyasha, Sheiller, \& Vhuramai, 2013). Knowledge management is significant due to the role it assumes through its processes and practices aiming at creating a positive atmosphere at the organizational context, enriching work, and promoting productivity (Alzou'bi \& Al-Zaidy, 2012), since knowledge management is considered as an indicator of a clear and comprehensive method for removing restrictions and restructuring that helps in the development and making of the change, in order to keep up with the requirements of realizing the strategic and operational objectives of the organization (Alzou’bi \& Al-Zaidy, 2012).

The successful organizations realize that they should direct their attention towards knowledge management processes: creation, conversion, spreading of and contribution to knowledge, as well as the methods of storing, selecting, and processing, using and assessing knowledge to excel in their performance. Sharing of knowledge has become critical for making use of the knowledge assets and 
using them properly. This is because sharing of knowledge can be deemed as an indispensable part for the organization, because the knowledge arising from within the organizations requires conveying and sharing of this knowledge in order to understand it (Masa'deh et al., 2016). Explicit and tacit knowledge is the main resource of the companies for obtaining and maintaining a competitive advantage. Sharing and integration of knowledge collects the scattered knowledge to promote innovation and creation, which eventually leads to the gains that improve performance (Piri, Jasemi, \& Abdi, 2013). There are many current practices of sharing of knowledge, such as training and development programs, IT systems, reports and official documents, and multifunctional teams, since knowledge sharing collects knowledge over a wide spectrum or different environments in order to promote the quality of products and services, increase the response to the clients' needs, enhance the ability to innovate and improve the performance of organization (Wang et al., 2014). Alzou'bi \& Al Zaidy (2012) explained by quoting from Hassan (2008) that generation or creativity of knowledge can be done through the participation of work teams and the work groups supporting the generation of a new knowledge capital in new issues and practices, which contribute to identifying problems and finding new solutions in an innovative, constant manner. The generation of knowledge refers to the organization's ability to develop new, beneficial ideas and solutions in respect of various organizational activities, from the products and technological processes to the administrative practices.

It also provides the organization with the ability to excel in accomplishment, realizing a high market standing on various areas such as practicing the strategy, starting new lines of action, expediting problem solving, transferring the best practices, developing the professionals' skills, and helping the management in employing and retaining talents. The purpose and objective of knowledge management is the application of the knowledge available for the organization, which is one of its most prominent processes; application of knowledge means making it more suitable for using in executing the organization activities and more relevant to the tasks it undertakes (Shariatmadari \& Forouzandeh, 2015).

Meanwhile, knowledge storage is the process of recovering knowledge, whether it is held by individuals or it is an organizational one, in a way facilitating the recovery of the same. The easy, regulated process of knowledge recovery, without contacting the person who originally developed such knowledge, saves time and other organizational resources and subsequently improves performance (Mothe, Nguyen-Thi, \& Nguyen-Van, 2015). Therefore, the following hypothesis is formulated:

H3: There is a positive effect of Knowledge Management Process on Organization Performance.

\section{Knowledge Management Process and Intellectual Capital}

There is a strong association between Knowledge Management Process and Intellectual Capital, and each complements the other. In addition to this, there are many important interferences (i.e., complement each other and constitute the knowledge assets of the organization) between them, and they make up the core of today's active management (Hsu \& Sabherwal, 2011; Wiig, 1997). Intellectual capital became a crucial resource of knowledge (Mehralian et al., 2014). Knowledge Management Process is a means to increase the intellectual capital, which ensures the success of an organization. All Knowledge Management Processes (generation, acquisition, documentation, storage, sharing, and application of knowledge) have an impact on intellectual capital (Seleim \& Khalil, 2011). All Knowledge Management Process activities that aim to capturing, gaining, documenting and sharing knowledge as well as its applications have a huge impact on intellectual capital (Hussinki et al., 2017). Mehralian et al. (2014) pointed out that knowledge acquisition is the organization's ability to determine, organize, and obtain knowledge from external resources and is vital to its operational success. It results in accumulating new knowledge and updating current knowledge, and therefore, plays a crucial role in developing human capital.

Wang et al. (2014) believes that knowledge is the main resource that shapes the organizational ability or the knowledge-based capital. However, knowledge has remained isolated and kept inside individu- 
als' minds or at certain administrative levels and units. It is difficult for the organization to take full advantage of the available knowledge and to accumulate or develop the intellectual capital from that. Whereas, the effective application of Knowledge Management Process strengthens organization learning at all levels through promoting human resources and personal experiences to formulate new ideas for developing and marketing new products. Also, there is a belief that application of Knowledge diversifies and develops intellectual capital (Ramadan et al., 2017). Therefore, the hypothesis is developed as follows:

H4: There is a positive effect of Knowledge Management Process on Intellectual Capital.

\section{Intellectual Capital and Organization Performance}

Kamukama, Ahiauzu, \& Ntayi (2011) confirmed that competitive advantage arises from the use of scarce, intangible, and firm-specific assets. Also, the firm current and future competitiveness as well as firm value growth are determined by intellectual capital. Tovstiga \& Tulugurova (2009) observed that competitive advantage is achieved by those firms that succeed in mobilizing their intellectual capital in the form of knowledge, technological skills, experience, and strategic capabilities. Intellectual capital, therefore, depicts resources and competencies that are valuable, and uncommon, which gives a lasting competitive advantage and superior performance to the firm (Kamukama, Ahiauzu, \& Ntayi, 2010), and human capital is the human factor in the organization, which is gathering in the intelligence, skills, and expertise that employees use and exploit when they leave the organization and gives its distinctive feature (Bontis, 2002). Meanwhile, the macroeconomic perspectives consider human capital as the driver of national economic activity, competitiveness and prosperity of a firm, and as the source of innovation and strategic renewal (Kamukama et al., 2011). Intellectual capital considers what happens among the people, and how the people are connected within the company (Halim, 2010, p. 63); intellectual capital is a stock of knowledge that is owned by the organization and includes information system, and explicit knowledge, product and process innovation, process optimization. Relational capital considered as an intangible asset that is based on developing, maintaining and nurturing high-quality relationships with any organization, individual or group that influences or impacts your business (Kamukama et al., 2011). Thus, we propose the following hypothesis:

H5: There is a positive effect of Intellectual Capital on Organization Performance.

\section{RESEARCH METHODOLOGY}

\section{OPERATIONAL MEASURES}

In order to achieve the main goal of the study, a survey questionnaire was used as a major instrument to collect data on selected variables. The questionnaire used in this study was divided into two parts. The first part asks about the demographics of the respondents (i.e., gender, education level, position, and years of experience), and the second part examines the selected variables, namely, Knowledge Management Infrastructure, Knowledge Management Process, Intellectual Capital and Organization Performance. In measuring the variables, the five point Likert-scales ranging from " 1 " for "strongly disagree" to " 5 " for "strongly agree" were adopted.

The questionnaire includes 43 items to measure the model constructs. Those items were selected from preceding empirical research. Minor modifications were made on these items to fit the food industry in Jordan, our research context. The measurements were adapted from previous studies. The dimensions of Knowledge Management Infrastructure (Organizational Culture, IT Infrastructure, and Organizational Structure) were adapted from the studies by Hajir et al. (2015), López et al. (2009), Mikkawi et al. (2017), and Valaei at el. (2017). The dimensions of Knowledge Management Process (Knowledge Generation, Knowledge Storage, Knowledge Sharing, and Knowledge Application) were adapted from the studies by Kasasbeh (2015), Sweis et al. (2011), Valaei et al. (2017), and Wang et al. (2014). In addition, the dimensions of Intellectual Capital (Human Capital, Structural 
Capital, and Relational Capital) were adapted from the studies of Abed Al-Qader (2014), Bontis (1998), and Hsu \& Sabherwal (2011); and Organization Performance (Non-financial performance, and Financial performance) were adapted from the studies by Tomislav et al. (2012) and Wang et al. (2014).

\section{Study Sample}

The food sector is one of the most important Jordanian industrial sectors, which has a multiplicity and diversity of products offered in local markets in Jordan. It is one of the most significant pillars of food security, as it works to increase the added value of the agricultural sector. Based on Jordan's Chamber of Industry (http://www.jci.org.jo/), the number of food organizations in this sector was 15 in 2017. Out of the 15 organizations, three of them, namely, Aljuneidi, Hamoudeh, and Danish Jordanian dairy companies, agreed to participate in the current research. Based on the employee availability, a convenience sample of 134 employees' from all levels (including top level management, middle level management, low level management) from the three organizations were selected. The study used the comprehensive survey for all workers at all levels with the help of the human resources management. During the data collection process, 134 questionnaires were distributed by hand; 11 of these questionnaires were considered unacceptable owing to inconsistencies in responses. Consequently, 123 completed questionnaires were used for data analysis.

\section{Respondents Demographic Profile}

As indicated in Table 1, the demographic profile of the respondents for this study shows that, the proportion of males is more than females. Most respondents hold a Bachelor degree (88.6\%), 68.3\% considered as middle level management, and $75.6 \%$ of them have experience between 5 -less than 10 years.

Table 1. Description of the respondents' demographic profiles

\begin{tabular}{|c|c|c|c|}
\hline Demographics & Category & Frequency & Percentage $\%$ \\
\hline \multirow[t]{3}{*}{ Gender } & Males & 71 & 57.7 \\
\hline & Female & 52 & 42.3 \\
\hline & Total & 123 & 100 \\
\hline \multirow[t]{3}{*}{ Qualification } & High school or less & 14 & 11.4 \\
\hline & Bachelor & 109 & 88.6 \\
\hline & Total & 123 & 100 \\
\hline \multirow[t]{4}{*}{ Position } & Top level management & 36 & 29.3 \\
\hline & $\begin{array}{l}\text { Middle level manage- } \\
\text { ment }\end{array}$ & 84 & 68.3 \\
\hline & Low level management & 3 & 2.4 \\
\hline & Total & 123 & 100 \\
\hline \multirow{3}{*}{$\begin{array}{l}\text { Years of experi- } \\
\text { ence }\end{array}$} & Less than 5 years & 30 & 24.4 \\
\hline & 5 - less than 10 years & 93 & 75.6 \\
\hline & Total & 123 & 100 \\
\hline
\end{tabular}

\section{RESEARCH RESULTS}

Construct validity was assessed using exploratory and confirmatory factor analyses. Exploratory factor analysis was performed using promax rotation method and principal component analysis. We entered all the question items simultaneously. Consequently, we got four distinct factors as was initially 
expected (i.e., Knowledge Management Infrastructure (KI), Knowledge Management Process (KP), Intellectual Capital (IC) and Organization Performance (OP). Eigenvalues for the four factors were greater than 1.0 respectively. Cronbach's $\alpha$-coefficient was applied to test the reliability of the constructs. The reliability of the constructs were satisfactory with $\alpha>0.60$ indicating acceptable internal consistency (Hair, Black, Babin, \& Anderson, 2010). Next, confirmatory factor analysis (CFA) was applied based on the output of EFA using Amos 20. All items exceeded loadings of 0.50 (Hair et al., 2010). The items of each measurement scale are included in Appendix A. Table 2 shows the fit indices for the first order constructs.

Table 2. Measurement model fit indices of first order constructs

\begin{tabular}{|l|l|l|l|l|l|l|l|l|l|l|}
\hline Model & $\mathrm{x}^{2}$ & $\mathrm{df}$ & $\mathrm{p}$ & $\mathrm{x}^{2} / \mathrm{df}$ & GFI & CFI & NFI & NNFI & RMR & RMSEA \\
\hline Final Model & 519.696 & 295 & 0.000 & 1.761 & 0.926 & 0.937 & 0.916 & 0.928 & 0.046 & 0.040 \\
\hline
\end{tabular}

The fit indices of the final model using first order constructs showed satisfactory levels $\left(\mathrm{x}^{2}=\right.$ 519.696; $\mathrm{df}=295 ; \mathrm{x}^{2} / \mathrm{df}=1.761 ; \mathrm{GFI}=0.926 ; \mathrm{CFI}=0.937$; NFI $=0.916 ; \mathrm{NNFI}=0.928 ; \mathrm{RMR}=$ 0.046 and RMSEA $=0.040)$. The normed chi-square of 1.791 was below the maximum value of 3.0 (Bollen, 1989). Goodness-of-fit index (GFI), comparative fit index (CFI), normed-fit index (NFI) and non-normed fit index (NNFI) were higher than the recommended minimum value of 0.90 (Garver \& Mentzer, 1999). Root mean square residual (RMR) was 0.046 and root mean square error of approximation (RMSEA) was 0.040 implying satisfactory level of unidimensionality and convergent validity (Garver \& Mentzer, 1999; Hu \& Bentler, 1999).

Furthermore, the standardized coefficients for all the question items were higher than twice of their standard errors, providing additional support for convergent validity (Anderson \& Gerbing, 1988). Besides, the factor loadings of all the items were greater than 0.50. In addition, average variance extracted (AVE) values for all the measurement scales were higher than 0.50 providing additional evidence of convergent validity (Fornell \& Larcker, 1981). The composite reliability of all the scales was greater than 0.70 providing a satisfactory level of reliability (Fornell \& Larcker, 1981; Garver \& Mentzer, 1999). Appendix B shows the standardized factor loadings of EFA and CFA, Cronbach's alpha values and composite reliability of the first and second order constructs. Indeed, CFA analyses were repeated using second order factors of Intellectual Capital on Organization Performance. Table 3 demonstrates the fit indices for the second order constructs.

Table 3. Measurement model fit indices of second order constructs

\begin{tabular}{|l|l|l|l|l|l|l|l|l|l|l|}
\hline Model & $\mathrm{x}^{2}$ & $\mathrm{df}$ & $\mathrm{p}$ & $\mathrm{x}^{2} / \mathrm{df}$ & GFI & CFI & NFI & NNFI & RMR & RMSEA \\
\hline Final Model & 520.322 & 272 & 0.000 & 1.912 & 0.942 & 0.954 & 0.916 & 0.941 & 0.039 & 0.039 \\
\hline
\end{tabular}

The final model fit indices using second order constructs fitted the data well $\left(\mathrm{x}^{2}=520.322 ; \mathrm{df}=272\right.$; $\mathrm{x}^{2} / \mathrm{df}=1.912 ; \mathrm{GFI}=0.942 ; \mathrm{CFI}=0.954 ; \mathrm{NFI}=0.916 ; \mathrm{NNFI}=0.941 ; \mathrm{RMR}=0.039$ and RMSEA $=0.039)$. These indices indicated an acceptable level of unidimensionality and convergent validity. Also, the standardized coefficients of all the constructs were higher than twice of their standard errors, providing evidence of convergent validity (Anderson \& Gerbing, 1988). Moreover, all the factor loadings were higher than 0.50. Likewise, average variance extracted (AVE) values for all the constructs exceeded 0.50 supporting the convergent validity (Fornell \& Larcker, 1981). The composite reliability of the two second order constructs exceeded 0.70 indicating sufficient levels of reliability (Fornell \& Larcker, 1981; Garver \& Mentzer, 1999).

Discriminant validity was assessed by ensuring that the square root of each AVE value is greater than the absolute correlation value between that scale and other scales. All first and second order constructs met this criterion providing sufficient evidence of discriminant validity (Fornell \& Larcker, 
1981). In addition, The AVE value for each construct was higher than maximum shared squared variance (MSV) and average shared squared variance (ASV) values providing further evidence of discriminant validity (Hair et al., 2010).

Table 4 reports discriminant validity results for first order constructs and Table 5 reports the results of the final model with second order constructs.

Table 4. Means, standard deviations, AVE, MSV, ASV and correlation matrix of first order constructs*

\begin{tabular}{|l|l|l|l|l|l|l|l|l|l|l|l|l|}
\hline Construct & Mean & SD & AVE & MSV & ASV & 1 & 2 & 3 & 4 & 5 & 6 & 7 \\
\hline 1. KG & 3.256 & 1.037 & 0.512 & 0.322 & 0.245 & $\mathbf{0 . 7 1 5}$ & & & & & & \\
\hline 2. KT & 3.761 & 0.867 & 0.524 & 0.312 & 0.224 & 0.672 & $\mathbf{0 . 7 2 3}$ & & & & & \\
\hline 3. KS & 3.447 & 1.063 & 0.568 & 0.320 & 0.219 & 0.535 & 0.672 & $\mathbf{0 . 7 5 3}$ & & & & \\
\hline 4. KA & 3.695 & 0.684 & 0.611 & 0.347 & 0.232 & 0.563 & 0.569 & 0.652 & $\mathbf{0 . 7 8 1}$ & & & \\
\hline 5. OC & 3.380 & 0.684 & 0.535 & 0.359 & 0.198 & 0.511 & 0.541 & 0.567 & 0.569 & $\mathbf{0 . 7 3 1}$ & & \\
\hline 6. IT & 3.829 & 0.638 & 0.667 & 0.258 & 0.136 & 0.469 & 0.421 & 0.452 & 0.513 & 0.579 & $\mathbf{0 . 8 1 6}$ & \\
\hline 7. OS & 3.575 & 0.629 & 0.687 & 0.219 & 0.139 & 0.412 & 0.458 & 0.411 & 0.447 & 0.511 & 0.622 & $\mathbf{0 . 8 2 8}$ \\
\hline
\end{tabular}

*Average Variance Extracted (AVE), Maximum Shared Squared Variance (MSV), Average Shared Squared Variance (ASV). Square root value of AVE is on the diagonal.

Table 5. Means, standard deviations, AVE, MSV, ASV and correlation matrix of second order constructs*

\begin{tabular}{|l|l|l|l|l|l|l|l|l|l|l|}
\hline Construct & Mean & SD & AVE & MSV & ASV & 1 & 2 & 3 & 4 & 5 \\
\hline 1. HC & 3.727 & 0.655 & 0.723 & 0.423 & 0.348 & $\mathbf{0 . 8 5 0}$ & & & & \\
\hline 2. SC & 3.823 & 0.578 & 0.636 & 0.412 & 0.321 & 0.679 & $\mathbf{0 . 7 9 7}$ & & & \\
\hline 3. RC & 3.796 & 0.551 & 0.619 & 0.358 & 0.299 & 0.544 & 0.611 & $\mathbf{0 . 7 8 6}$ & & \\
\hline 4. NP & 3.994 & 0.724 & 0.522 & 0.389 & 0.297 & 0.457 & 0.602 & 0.508 & $\mathbf{0 . 7 2 2}$ & \\
\hline 5. FP & 3.997 & 0.717 & 0.516 & 0.401 & 0.301 & 0.419 & 0.409 & 0.398 & 0.455 & $\mathbf{0 . 7 1 8}$ \\
\hline
\end{tabular}

*Average Variance Extracted (AVE), Maximum Shared Squared Variance (MSV), Average Shared Squared Variance (ASV).Square root value of AVE is on the diagonal.

Structural Equation Modeling (SEM) using Amos 20 was performed to test the study hypotheses. SEM allows simultaneous testing of all hypotheses including direct and indirect effects. Additionally, SEM has the option of applying bootstrapping re-sampling approach to test the mediating effect. Bootstrapping is superior to the approach described by Baron \& Kenny (1986) as normal distribution assumption of the indirect effect is not required and the accuracy of the results is not affected by the sample size (Hayes, 2009). As recommended by Hayes (2013), we selected 5,000 bootstrap samples with $99 \%$ bias-corrected confidence intervals. An alternative hypothesis regarding the mediating effect is accepted if the lower and upper bounds of confidence intervals do not contain zero. This implies that the indirect effect is not zero with $99 \%$ confidence level. If the two bounds contain zero, then the alternative hypothesis is rejected (Hayes, 2013). Table 6 provides a summary of the tested hypotheses.

The results of the direct effects show that Knowledge Management Infrastructure is positively and significantly related to Knowledge Management Process $(\beta=0.760, \mathrm{P}<0.000)$; therefore, hypothesis 
H1 is supported. Also, Knowledge Management Process is positively and significantly related to Organization Performance $(\beta=0.181, \mathrm{P}<0.05)$; so hypothesis $\mathrm{H} 3$ is also supported. The direct effect of Knowledge Management Process on Intellectual Capital is also positive and significant $(\beta=0.179$, $\mathrm{P}<0.05)$; therefore, hypothesis $\mathrm{H} 4$ is supported. Intellectual Capital is positively and significantly related to Organization Performance $(\beta=0.776, \mathrm{P}<0.000)$. Hypothesis $\mathrm{H} 5$ is also supported. However, $\mathrm{H} 2$ was not supported $(\beta=0.015)$.

Table 6. Summary of results

\begin{tabular}{|l|l|l|l|}
\hline Hypothesis & Path & Standardized effect & Result \\
\hline $\mathrm{H} 1$ & $\mathrm{KI} \rightarrow \mathrm{KP}$ & $0.000^{* * *}$ & Supported \\
\hline $\mathrm{H} 2$ & $\mathrm{KI} \rightarrow \mathrm{OP}$ & 0.190 & Not Supported \\
\hline $\mathrm{H} 3$ & $\mathrm{KP} \rightarrow \mathrm{OP}$ & $0.023^{*}$ & Supported \\
\hline $\mathrm{H} 4$ & $\mathrm{KP} \rightarrow \mathrm{IC}$ & $0.044^{*}$ & Supported \\
\hline $\mathrm{H} 5$ & $\mathrm{IC} \rightarrow \mathrm{OP}$ & $0.000^{* * *}$ & Supported \\
\hline $\begin{array}{l}\text { Notes: } * * * \mathrm{p}<0.001 ; * * \mathrm{p}<0.01 ; * \mathrm{p}<0.05 ; \text { KI: Knowledge Management Infrastructure, KP: } \\
\text { Knowledge Management Process, IC: Intellectual Capital, OP: Organization Performance }\end{array}$ \\
\hline
\end{tabular}

Further, the coefficient of determination $\left(\mathrm{R}^{2}\right)$ for Knowledge Management Process, Intellectual Capital and Organization Performance were $0.58,0.32$ and 0.68 respectively, which indicates that those constructs at least moderately account for the variation of the proposed model.

\section{DISCUSSION OF RESULTS}

The aim of this research is to investigate the interrelationships among Knowledge Management Infrastructure, Knowledge Management Process, Intellectual Capital and Organization Performance. The results of the direct effects show that Knowledge Management Infrastructure (Organizational Culture, IT Infrastructure, and Organizational Structure) is positively and significantly related to Knowledge Management Process. Therefore, H1 was supported. This result agrees with the findings of Theriou et al. (2011). They found a positive relationship between Knowledge Management Infrastructure and Knowledge Management Process. An effective culture of knowledge management consists of rules and practices that promote the transfer of information and knowledge among staff and across different administrative levels.

Kushwaha \& Rao (2015) emphasized that information technology plays an important role in knowledge management. It is one of the fundamental points of knowledge management. It helps in the process of sharing, transmitting, disseminating, generating, and documenting knowledge. Information technology is an indispensable tool for discovering knowledge, and also there are "Collaborative IT" tools that allow employees to work together and collaborate interactively, thus the tacit knowledge of individuals is transformed into explicit and organizational knowledge through knowledge sharing. The study also support results from Cortés et al. (2007), which indicated that the organizational structure is one of the most influential elements in the implementation of Knowledge Management Process in the organizations. Excellence in knowledge management should have flexible organizational structures; flat structures allow an organization not only to share knowledge but also to collaborate to create new knowledge in all its services. Organizations must adopt organizational structures that allow them to generate, share, and transfer as much knowledge as possible.

Interestingly our results showed that the three dimensions of Knowledge Management Infrastructure (Organizational Culture, IT Infrastructure, and Organizational Structure) did not significantly impact Organization Performance directly, so hypothesis $\mathrm{H} 2$ was not supported. This was consistent with 
the study of Mills \& Smith (2011), which indicated that there was an indirect impact of knowledge management infrastructure capabilities (Organizational Culture, and IT Infrastructure), except organizational structure which had a direct impact on the performance of organizations. However, not all knowledge resources were contributors to the development of organization performance. Resources such as information technology and the organizational culture are necessary to increase the effectiveness of knowledge management. Knowledge Management Infrastructure did not influence the organizational performance directly; organizations cannot ignore these dimensions namely Organizational Culture, IT Infrastructure, and Organizational Structure because they work in cycle with other organizational resources. Further, organizations cannot conceal the role of these dimensions as providers of organizational resources in terms of acquisition, application and sharing knowledge that can directly contribute to the success of the organization.

Knowledge Management Process is positively and significantly related to Organization Performance. This result is consistent with the results of the studies by Wang, Wang, Cao, \& Ye (2016) and Jyoti \& Rani (2017). Knowledge management also contributes to managing organizational knowledge assets and enhancing creativity and innovation in performance. This result agrees with the finding from the study by Tan \& Wong (2015) which concluded that knowledge management is a key that contributes to improving performance and helps to create an efficient production environment. Knowledge assets play a key role in the performance and facilitation of the organization's daily manufacturing activities. Manufacturing organizations own their machinery, which needs useful knowledge based on IT intelligent systems to enhance production and remain at the forefront of competition. In addition to many other benefits, knowledge management processes can bring in up-to-date production information and solve problems in a creative way and in short time, as well as improve and renovate the products.

Studies by Tubigi \& Alshawi (2015) and Shahzad, Bajwa, Siddiqi, Ahmid, \& Sultani (2016) also pointed out that there is a direct positive impact of knowledge management processes on the performance of organizations. Knowledge management helps organizations to create knowledge and to share, acquire, and benefit from it by applying it. Organizational knowledge is an important asset for a competitive advantage and as an effective contributor to the success and survival of organizations within a highly complex competitive trading environment. In an organization that depends more on their products, services, and knowledge, the creation, generation and exchange of new knowledge becomes a vital source of competitive advantage. Accordingly, knowledge management enables organizations to perform better than their competitors.

The direct effect of Knowledge Management Process on Intellectual Capital is also positive and significant $(\beta=0.179, \mathrm{P}<0.05)$ in our study. Knowledge Management Process affects and helps building intellectual capital to large extent. This result agrees with those from the study by Seleim $\&$ Khalil (2011). Generally, there was a positive impact of applying knowledge to human capital and relational capital, and a positive impact of transferring knowledge to relational capital. In fact, the application of practical knowledge was the most influential of the three dimensions of intellectual capital (human, regulatory, and relational). This result agrees with the finding by Ramadan et al. (2017) that showed that the entire knowledge management process (knowledge acquisition, knowledge generation, knowledge documentation, and knowledge transfer) had significant positive effects on intellectual capital.

Our data analysis results revealed that Intellectual Capital was positively and significantly related to Organization Performance $(\beta=0.776, \mathrm{P}<0.000)$. This study is supported by previous study by Uzoma, Ugwoke, \& Rita (2017) which confirmed that intellectual capital and organizational performance were positively linked. The positive relationship between intellectual capital and the performance of organizations was due to the important role that was played by components of intellectual capital in the organization. Structure capital is important for innovation and performance improvement, because the organizational knowledge represented in databases, structures, systems, processes and patents helps to enhance existing knowledge and, in turn, facilitates the ability to innovate. Our 
results also agree with the finding from the study by Seleim's et al. (2007) which pointed out that the positive relationship between organizational performance and human capital is based on a high level of intelligence, creative ideas, and ambition. Human capital has the skills, the knowledge, and the talent with which it is able to offer unique and smart products and services that will gain customer satisfaction. Intellectual capital can be developed and better used by adopting management practices and strategies that create added value in the organization, and will impact long-term organizational performance.

Sharing, application, and generation of knowledge are key determinants for enhancing the benefits of performance gained from intellectual capital. The added value of human capital, structural capital, and relational capital can be achieved by sharing knowledge which is acquired from different functional areas and organizational levels. Managers should remove all potential barriers to knowledge generation and sharing and facilitate collaboration and networking for knowledge application to achieve superior performance. This study is designed to clarify the relationship between knowledge management and intellectual capital and its impact on the organization's performance. We believe that ideas-based on knowledge are the foundations and motivations of organizations' performance. The study results coincided with the findings from the study by Hussinki and his colleagues (2017).

\section{CONCLUSIONS}

This study is aimed to examine the relationship between the knowledge resources in organizations that were represented in knowledge management processes (knowledge generation, knowledge sharing, knowledge storage, knowledge application) and intellectual capital (human capital, relational capital). It also aimed to test the role of knowledge management infrastructure as an instrumental and enabler factor in the organization's knowledge resources, knowledge management and intellectual capital. Results of the study showed a direct impact of knowledge management infrastructure on the knowledge management process and intellectual capital; the study also shows a direct impact of knowledge management processes and intellectual capital on the performance of organizations. Knowledge management infrastructure had insignificant direct effect on organizational performance. Knowledge management and intellectual capital serve as an intermediary between knowledge management infrastructure and organization performance.

\section{RESEARCH AND MANAGERIAL IMPLICATIONS}

The theoretical contribution of this study encompasses developing an integrated model of knowledge resources, its enabling factors, and demonstrating its role in improving organizational performance. The research model is a comprehensive framework for organizations that seek to get superior performances through their knowledge resources of knowledge management process and intellectual capital. This study differed from those studies conducted in the Jordanian business environment because it presented an integrated model which shows how knowledge management in terms of infrastructure, process, and intellectual capital relates to organizational performance.

This research also offers several useful recommendations to managers within organizations, especially in the food industry in Jordan. Managers should help to create a suitable environment for smooth knowledge sharing among all employees in the organization and provide advanced technological tools through constant upgrading and updating, especially, the hardware and software that contribute to the dissemination and sharing of knowledge, and databases to store knowledge to facilitate knowledge retrieval. Furthermore, researchers (Amali \& Katili, 2018; Masa'deh et al., 2016; Obeidat et al., 2017) stressed the important role of knowledge management capabilities in improving organization performance in private and public sectors. Consequently, managers can use the current research model that facilitates their work places to end with a better organizational performance results. Also, our research model can contribute to economies of scale and scope by focusing on the organization's capability to create and leverage knowledge related to products, customers, and managerial resources among businesses. 
Transferring directly to flexible organizational structures (flat structure) encourages and enhances teamwork, projects haring, job rotation, and provides formal and informal channels of communication such as brain storming sessions and meeting rooms to promote and facilitate the exchange of ideas. Eliminating centralization helps to empower and maintain human capital, which is the heart of the organization's knowledge resources. This requires activating the role of the customer or relational capital by opening effective channels of communication with these organizations to exchange experiences and skills, so that their employees can learn about international experiences in the food industry, because this will lead to superior performance. Also, food companies in Jordan would improve their structural capital based on knowledge management capabilities, which could assist the work of research and development (R\&D) departments, which leads to innovation and will certainly reflect on financial and non-financial organizational performances.

\section{LIMITATIONS AND FUTURE RESEARCH DIRECTIONS}

Due to the large number of industrial food organizations in Jordan, and based on the agreement of few of them to participate in the current study, we cannot generalize our research findings. Indeed, this study was implemented on a certain group of food companies. We were not able to cover and deliver the questionnaire to all the food companies available in Jordan, thus the percentage of those who did not respond was still observable; consequently, further research is needed with higher response rate. Kline (2010) suggested that a sample of 200 or larger is appropriate for performing Structural Equation Modeling (SEM) analysis. However, after eliminating the incomplete survey for the current research, our sample size consisting of 123 did not meet the recommended guidelines of Kline (2010). Therefore, for the generalizability purposes, future research should consider higher response rates. Also, future studies considering the impact of KM infrastructure on the performance of the Small and Medium Enterprises (SMEs) could be useful for the food industry sector.

In addition, organizational cultures are considered a complex set of formal and informal systems, processes, and interactions. Shannak, Obeidat, \& Masa'deh (2012) argued that managers should depend on employees who are fully knowledgeable of their culture to increase the possibility of successfully implementing their strategic decisions. Formal organizational culture covers leadership, structure, policies, reward systems, socialization mechanisms, decision-making processes, etc. Informal organizational culture contains implicit behavioral norms, values, role models, organizational myths and rituals, organizational beliefs, historical anecdotes, and language (Akhavan, Sanjaghi, Nour, \& Ojaghi, 2014). Consequently, future research could investigate the associations among formal and informal organizational culture, knowledge management, and organizational performance.

Also, further research is needed to examine and confirm our research findings. This could be performed on food companies and other sectors such as banks and financial and investments firms. Further, it will be worth learning if our research findings will be confirmed in other contexts and in different regions. Such learning encourages us to generalize our findings and might explore other unstudied factors of the interrelationships among knowledge management infrastructure, knowledge management process, intellectual capital, and organization performance.

In addition, organizations that contain knowledgeable human capital are likely to outperform those with low levels of knowledge based human capital. Gupta, Massa, \& Azzopardi (2016) believe that knowledgeable intellectual capital enhances superior performance and achieves unique competitive advantage. Therefore, an organization with high levels of human based intellectual capital; along within effective use of knowledge management capabilities can increase the organizational competitive advantage. Also, Gupta et al. (2016) stated that organizational culture is considered as a stimulating environment in which organizations can grow and thrive. Intellectual capital flourishes and grows only with a supportive organizational culture, particularly human capital, through the creation of a cultural climate that encourages creativity, innovation, and flexibility. Even if organizations do not have an ideal culture, they can seek to build an organizational culture to support the use of intellectual capital and sustain the growing of the organization. Consequently, further research is needed to 
examine the associations among knowledgeable human capital, knowledge management capabilities, and organizational performance in terms of creativity and innovation.

Al-Khateeb, Massa, \& Azzopardi (2007) indicated that the relationship between the role of information technology and human capital and their impact on the growth and development of organizations in the long term. Also, they found a strong and positive relationship between the economic growth in organizations in all sectors with information technology and the accumulation of human capital. This result emphasizes the importance of both information technology and human capital in economic growth. In fact, information technology and human capital complement each other and must be addressed in parallel. Consequently, future research should examine the indirect effect of Knowledge Management Infrastructure on Intellectual Capital via the mediating effect of Information Technology.

Also, since organizations are increasingly demonstrating the competitive advantages of knowledge resources, knowledge resources and intellectual capital are currently the most important organizational assets and both variables have been used by organizations that seek competitive advantage (Chang \& Lin, 2015). Organizations increasingly rely on intangible and knowledge-driven intellectual assets to succeed. Knowledge creation, sharing and application are the main factors that generate or create the added value of an organization (Hussinki et al., 2017; Mehralian et al., 2014). For instance, Obeidat et al. (2017) showed that knowledge sharing effectively mediates the relationship between intellectual capital and organizational performance, which means that industrial organizations rely heavily on intellectual capital and knowledge sharing to enhance their organizational performance. Thus, researchers would investigate further the association among intellectual capital, knowledge sharing and organizational performance.

\section{REFERENCES}

Abed Al-Qader, S. W. (2014). Measuring the effect of factors of the organizational culture and knowledge management on competitive advantage: Case study of Jordanian telecom company (Orange). Unpublished master's thesis, Middle East University, Amman, Jordan.

Abualloush, S., Bataineh, K., \& Aladwan, A. (2017). Impact of information systems on innovation (product innovation, process innovation) - Field study on the housing bank in Jordon. International Journal of Business Administration, 8(1), 1-12.

Acharya, A., \& Mishra, B. (2017). Exploring the relationship between organizational structure and knowledge retention: A study of the Indian infrastructure consulting sector. Journal of Knowledge Management, 21(4), 961-985. https://doi.org/10.1108/JKM-11-2016-0506

Akhavan, P., Sanjaghi, M. E., Nour, J. R., \& Ojaghi, H. (2014). Examining the relationships between organizational culture, knowledge management, and environmental responsiveness capability. The Journal of Information and Knowledge Management Systems, 44(2), 228-248.

Al-Ali, R. M. (2013). The relationship between knowledge management processes, organizational innovation and its effect on organizational performance: An applied study at the ICT (information and communication technology) sector in Jordan. Unpublished master's thesis, Middle East University, Amman, Jordan.

Al-Khateeb, F. B., Darrat, A. F., \& Elkhal, K. (2007). The UAE growth surge: Have information technology and human capital contributed. Studies in Economics and Finance, 24(4), 297-306. https://doi.org/10.1108/10867370710831846

Allameh, S. M., Zare, S. M., \& Davoodi, S. M. R. (2010). Examining the impact of KM enablers on knowledge management processes. Procedia Computer Science, 3, 1211-1223. https://doi.org/10.1016/j.procs.2010.12.196

Alrawabdeh, W. (2014). How employees' loyalty programs impact organizational, performance within Jordanian banks. International Business Research, 7(9), 119-129. https://doi.org/10.5539/ibr.v7n9p119 
Alrowwad, A., Obeidat, B., Tarhini, A., \& Aqqad, N. (2017). The impact of transformational leadership on organizational performance via the mediating role of corporate social responsibility: A structural equation modeling approach. International Business Research, 10(1), 199-221. https://doi.org/10.5539/ibr.v10n1p199

Al-Shanti, M. A. (2017). The role of transformational leadership on the knowledge management: An applied study on the employees in the Palestinian interior ministry-Gaza strip. The Jordan Journal of Business Administration, 13(3), 435-459. https://doi.org/10.12816/0039537

Al-Ti, A. (2016). The mediating role of knowledge management and the moderating part of organizational culture between HRM practices and organizational performance. International Business Research, 9(1), 43-54. https://doi.org/10.5539/ibr.v9n1p43

Alzou'bi, K. Y., \& Al-Zaidy, Z. H. (2012). The impact of management information systems (MIS) on knowledge management processes (KMP) as perceived by the employees working in the centers of ministries in Jordan. Dirasat: Administrative Sciences, Jordan University, 8(4), 147-160.

Amali, L., \& Katili, M. (2018). Identification of influential factors in implementing IT governance: A survey study of Indonesian companies in the public sector. Interdisciplinary Journal of Information, Knowledge, and Management, 13, 61-77. https://doi.org/10.28945/3975

Anderson, J. C., \& Gerbing, D. W. (1988). Structural equation modeling in practice: A review and recommended two-step approach. Psychological Bulletin, 103(2), 411-423. https://doi.org/10.1037/0033-2909.103.3.411

Attia, A., \& Salama, I. (2018). Knowledge management capability and supply chain management practices in the Saudi food industry. Business Process Management Journal, 24(2), 459-477. https://doi.org/10.1108/BPMJ$\underline{01-2017-0001}$

Baron, R., \& Kenny, D. (1986). The moderator-mediator variable distinction in social psychological research: Conceptual, strategic, and statistical considerations. Journal of Personality and Social Psychology, 51(6), 11731182. https://doi.org/10.1037/0022-3514.51.6.1173

Birasnav, M. (2014). Knowledge management and organizational performance in the service industry: The role of transformational leadership beyond the effects of transactional leadership. Journal of Business Research, 67, 1622-1629. https://doi.org/10.1016/i.jbusres.2013.09.006

Beveren, J. V. (2003). Does health care for knowledge management? Journal of Knowledge Management, 7(1), 90-95. https://doi.org/10.1108/13673270310463644

Bishop, J., Bouchlaghem, D., Glass, J., \& Matsumoto, I. (2008). Ensuring the effectiveness of a knowledge management initiative. Journal of Knowledge Management, 12(4), 16-29. https://doi.org/10.1108/13673270810884228

Bollen, K. A. (1989). Structural equations with latent variables. New York: John Wiley \& Sons.

Bontis, N. (1998). Intellectual capital: An exploratory study that develops measures and models. Management Decision, 36(2), 63-76. https://doi.org/10.1108/00251749810204142

Bontis, N. (2002). There is a price on your head: Managing intellectual capital strategically. Business Quarterly, $60(4), 40-47$.

Bouraghda, H. T., \& Dris, N. B. (2015). The impact of knowledge sharing on the human resources performance: A case study of TV and NR's production unit of CONDOR company in Algeria. The Jordan Journal of Business Administration, 11(4), 841-868.

Cania, L. (2014). The impact of strategic human resource management on organizational performance. Economia: Seria Management, 17(2), 373-383.

Carton, R. B. (2004). Measuring organizational performance: An exploratory study. Unpublished PhD thesis, University of Georgia, Athens.

Chang, C. L. H., \& Lin, T. C. (2015). The role of organizational culture in the knowledge management process. Journal of Knowledge Management, 19(3), 433-455. https://doi.org/10.1108/JKM-08-2014-0353

Chien, Y. C., Yuan, K., \& Hsiung, K. (2015). The influences of knowledge management on organizational performance of Taiwan-listed IC design houses: Using intellectual capital as the mediator. The Journal of International Management Studies, 54(10), 50-67. 
Knowledge Management Process and Organization Performance

Cortés, C. E., Zaragoza-Sáez, P., \& Ortega, E. P. (2007). Organizational structure features supporting knowledge management processes. Journal of Knowledge Management, 11(4), 45-57. https://doi.org/10.1108/13673270710762701

Dahiyat, S. E. (2015). An integrated model of knowledge acquisition and innovation: Examining the mediation effects of knowledge integration and knowledge application. International Journal of Learning and Change, 8(2), 101-135. https://doi.org/10.1504/IJLC.2015.074064

Dalkir, K. (2005). Knowledge management in theory and practice. Oxford: Elsevier Butter Worth Heinemann.

Drucker, P. (1994). The age of social transformation. The Atlantic Monthly, 274(5), 53-70.

Fernandez, I., \& Sabherwal, R. (2010). Knowledge management: Systems and processes. Armonk (N.Y.); London: M.E. Sharpe.

Fornell, C., \& Larcker, D. F. (1981). Structural equation models with unobservable variables and measurement error. Journal of Marketing Research, 18(1), 39-50. https://doi.org/10.2307/3151312

Gavrea, C., Ilieş, L., \& Stegerean, R. (2011). Determinants of organizational performance: The case of Romania. Management \& Marketing Challenges for the Knowledge Society, 6(2), 285-300.

Garver, M. S., \& Mentzer, J. T. (1999). Logistics research methods: Employing structural equation modelling to test for construct validity. Journal of Business Logistics, 20(1), 33-57.

George, C. H. (2014). Knowledge management infrastructure and knowledge sharing: The case of a large fast moving consumer goods distribution centre in the Western Cape. Master thesis, University of the Western Cape.

Gharakhani, D., \& Mousakhani, M. (2012). Knowledge management capabilities and SMEs' organizational performance. Journal of Chinese Entrepreneurship,4(1), 35-49. https://doi.org/10.1108/17561391211200920

Gold, A. H., Malhotra, A., \& Segars, A. H. (2001). Knowledge management: An organizational capabilities perspective. Journal of Management Information Systems, 18(1), 185-214. https://doi.org/10.1080/07421222.2001.11045669

Gupta, U. G., Massa, N. P., \& Azzopardi, J. (2016). Culture and intellectual capital: Towards a conceptual framework. International Journal of Organizational Analysis, 24(3), 438-453. https://doi.org/10.1108/IJOA06-2015-0871

Hair, J., Black, W., Babin, B., \& Anderson, R. (2010). Multivariate data analysis. Upper Saddle River, NJ: Prentice Hall.

Hajir, J. A., Obeidat, B. Y., Al-dalahmeh, M. A., \& Masa'deh, R. (2015). The role of knowledge management infrastructure in enhancing innovation at mobile telecommunication companies in Jordan. European Journal of Social Sciences, 50(3), 313-330.

Halim, S. (2010).Statistical analysis on the intellectual capital statement. Journal of Intellectual Capital, 11(1), 61-73. https://doi.org/10.1108/14691931011013334

Hayes, A. (2009). Beyond Baron and Kenny: Statistical mediation analysis in the new millennium. Communication Monographs, 76(4), 408-420. https://doi.org/10.1080/03637750903310360

Hayes, A. (2013). Introduction to mediation, moderation, and conditional process analysis. New York: The Guilford Press.

Hejase, H. J., Hejase, A. J., Tabsh, H., \& Chalak, H. C. (2016). Intellectual capital: An exploratory study from Lebanon. Open Journal of Business and Management, 4, 571-605. https://doi.org/10.4236/ojbm.2016.44061

Hsu, I. C. \& Sabherwal, R. (2011). From intellectual capital to firm performance: The mediating role of knowledge management capabilities. IEEE Transactions on Engineering Management, 58(4), 626-642. https://doi.org/10.1109/TEM.2011.2111455

Hu, L., \& Bentler, P. M. (1999). Cutoff criteria for fit indices in covariance structure analysis: Conventional criteria versus new alternatives. Structural Equation Modeling: A Multidisciplinary Journal, 6(1), 1-55. https://doi.org/10.1080/10705519909540118 
Hussinki, H., Ritala, P., Vanhala, M., \& Kianto, A. (2017). Intellectual capital, knowledge management practices and firm performance. Journal of Intellectual Capital, 18(4), 904-922. https://doi.org/10.1108/JIC-11-2016$\underline{0116}$

Imran, M. K. (2014). Impact of knowledge management infrastructure on organizational performance with moderating role of KM performance: An empirical study on banking sector of Pakistan. Information and Knowledge Management, 4(8), 85-98.

Jaradat, N. M., \& Al Maani, A. I. (2014). The impact of knowledge management infrastructure on performance effectiveness in Jordanian organizations. Arab Economic and Business Journal, 9, 27-36. https://doi.org/10.1016/j.aebj.2014.05.006

Jyoti, J., \& Rani, A. (2017). High performance work system and organisational performance: Role of knowledge management. Personnel Review, 46(8), 1770-1795. https://doi.org/10.1108/PR-10-2015-0262

Kamukama, N., Ahiauzu, A., \& Ntayi, J. M. (2010). Intellectual capital and performance: Testing interaction effects. Journal of Intellectual Capital, 11(4), 554-574. https://doi.org/10.1108/14691931011085687

Kamukama, N., Ahiauzu, A., \& Ntayi, J. M. (2011). Competitive advantage: Mediator of intellectual capital and performance. Journal of Intellectual Capital, 12(1), 152-164. https://doi.org/10.1108/14691931111097953

Kasasbeh, W. (2015). The impact of knowledge management in the development of a culture of excellence: An empirical study of the commercial banks operating in the city of Tabuk. Dirasat: Administrative Sciences, Jordan University, 42(2), 267-287.

Khalique, M., Shaari, J. A., \& Isa, A.H. (2011). Intellectual capital and its major components. International Journal of Current Research, 3(6), 343-347.

Kline, R. (2010). Principles and practice of structural equation modeling. The Guilford Press.

Kushwaha, P., \& Rao, M. K. (2015). Integrative role of KM infrastructure and KM strategy to enhance individual competence: Conceptualizing knowledge process enablement. VINE, 45(3), 376-396. https://doi.org/10.1108/VINE-02-2014-0014

Laudon, K., \& Laudon, J. (2014). Management information systems (12th ed.). New Jersey: Pearson Prentice Hall.

Lee, S. Y., Florida, R., \& Gates, G. (2010). Innovation, human capital, and creativity. International Review of Public Administration, 14(3), 13-24. https://doi.org/10.1080/12294659.2010.10805158

López, S. P, Peón, J. M., \& Ordás, C. J. (2009). Information technology as an enabler of knowledge management: An empirical analysis. Annals of Information Systems, 4, 111-128. https://doi.org/10.1007/978-1-4419$\underline{0011-1 \quad 8}$

Luiza, F. (2016). The role of intellectual capital in achieving the competitive advantage of economic institutions in the knowledge economy: Cement company case study. Unpublished doctorate thesis, Mohammad Khader University, Baskra, Algeria.

Maruf, H., \& Zhou, S. (2015). Knowledge management in global organization. International Business Research, $8(6), 165-173$.

Masa'deh, R. (2016). The role of knowledge management infrastructure in enhancing job satisfaction at Aqaba five star hotels in Jordan. Communications and Network, 8(4), 219-240.

https://doi.org/10.4236/cn.2016.84021

Masa'deh, R., Obeidat, B., \& Tarhini, A. (2016). A Jordanian empirical study of the associations among transformational leadership, transactional leadership, knowledge sharing, job performance, and firm performance: A structural equation modelling approach. Journal of Management Development, 35(5), 681-705. https://doi.org/10.1108/JMD-09-2015-0134

Mehralian, G., Nazari, J. A., Akhavan, P., \& Rasekh, H. R. (2014). Exploring the relationship between the knowledge creation process and intellectual capital in the pharmaceutical industry. The Learning Organization, 21(4), 258-273. https://doi.org/10.1108/TLO-07-2013-0032

Meihami, B., \& Meihami, H. (2014). Knowledge management a way to gain a competitive advantage in firms (evidence of manufacturing companies). International Letters of Social and Humanistic Sciences, 3, 80-91. 
Knowledge Management Process and Organization Performance

Mikkawi, B., Masa'deh, R., \& Al-Lozi, M. (2017). The impact of knowledge management infrastructure on academic staff effectiveness: An empirical, study at the University of Jordan. The Jordan Journal of Business Administration, 13(1), 95-127. https://doi.org/10.12816/0035049

Mills, M. A., \& Smith, T. A. (2011). Knowledge management and organizational performance: A decomposed view. Journal of Knowledge Management, 15(1), 156-171. https://doi.org/10.1108/13673271111108756

Mothe, C., Nguyen-Thi, U. T., \& Nguyen-Van, P. (2015). Assessing complementarity in organizational innovations for technological innovation: The role of knowledge management practices. Applied Economics, 47(29), 3040-3058. https://doi.org/10.1080/00036846.2015.1011320

Nonaka, I., Toyama, R., \& Konno, N. (2000). SECI, ba and leadership: A unified model of dynamic knowledge creation. Long Range Planning, 33, 5-34. https://doi.org/10.1016/S0024-6301(99)00115-6

Obeid, S. M., \& Rabay'a, S. (2016). The impact of knowledge management dimensions in the learning organization from the perspective of the Arab American University's (AAU) faculty-Palestine. Jordan Journal of Business Administration, 12(4), 813-840. https://doi.org/10.12816/0034970

Obeidat, B. (2016). Exploring the relationship between corporate social responsibility, employee engagement, and organizational performance: The case of Jordanian mobile telecommunication companies. International Journal of Communications, Network and System Sciences, 9, 361-386. https://doi.org/10.4236/ijcns.2016.99032

Obeidat, B., Al-dalahmeh, M., \& Masa'deh, R. (2015). The role of knowledge management infrastructure in enhancing innovation at mobile telecommunication companies in Jordan. European Journal of Social Sciences, 50(3), 313-330.

Obeidat, B., Al-Suradi, M., Masa'deh, R., \& Tarhini, A. (2016). The impact of knowledge management on innovation: An empirical study on Jordanian consultancy firms. Management Research Review, 39(10), 1214-1238. https://doi.org/10.1108/MRR-09-2015-0214

Obeidat, B., Tarhini, A., Masa'deh, R., \& Aqqad, N. (2017). The impact of intellectual capital on innovation via the mediating role of knowledge management: A structural equation modelling approach. International Journal of Knowledge Management Studies, 8(3-4), 273-298. https://doi.org/10.1504/IJKMS.2017.087071

Pandey, S. C., \& Dutta, A. (2013). Role of knowledge infrastructure capabilities in knowledge management. Journal of Knowledge Management, 17(3), 435-453. https://doi.org/10.1108/JKM-11-2012-0365

Pannu, H. (2017). The impact of knowledge management infrastructure on organizational performance in SMES. International Journal of Human Resource \& Industrial Research, 4(2), 26-31.

Pension, K., Nyasha, M., Sheiller, M., \& Vhuramai, C. (2013). Impact of knowledge management on organizational performance: A case study of grain marketing board (GMB). Greener Journal of Business and Management Studies, 3(6), 270-278. https://doi.org/10.15580/GJBMS.2013.6.071513733

Piri, M., Jasemi, M., \& Abdi, M. (2013). Intellectual capital and knowledge management in the Iranian space industries. VINE, 43(3), 341-356. https://doi.org/10.1108/VINE-08-2012-0036

Pirozzi, M. G., \& Ferulano, G. P. (2016). Intellectual capital and performance measurement in healthcare organizations: An integrated new model. Journal of Intellectual Capital, 17(2), 320-350. https://doi.org/10.1108/JIC-07-2015-0063

Pour, E. R., Masjedi, S., \& Akhavan, P. (2015). Exploring the relationship between knowledge management and intellectual capital: An Iranian university case study. International Journal of Management Academy, 3(1), 7-15.

Rai, R. K. (2011). Knowledge management and organizational culture: A theoretical integrative framework. Journal of Knowledge Management, 15(5), 779-801. https://doi.org/10.1108/13673271111174320

Ramadan, B., Dahiyat, S., Bontis, N., \& Al-dalahmeh, M. (2017). Intellectual capital, knowledge management and social capital within the ICT sector in Jordan. Journal of Intellectual Capital, 18(2), 437-462. https://doi.org/10.1108/JIC-06-2016-0067

Ranjbarfard, M., Aghdasi, M., López-Sáez, P., \& López, J. E. N. (2014). The barriers of knowledge generation, storage, distribution and application that impede learning in gas and petroleum companies. Journal of Knowledge Management, 18(3), 494-522. https://doi.org/10.1108/JKM-08-2013-0324 
Abualoush, Masa'deh, Bataineh, \&Alrowwad

Rehman, W. U., \& Abdul Rehman, C. (2015). Linking intellectual capital and knowledge management with organizational performance: A meta-review analysis. Kuwait Chapter of Arabian Journal of Business and Management Review, 5(2), 63-73.

Richard, P. J., Devinney, T., \& Yip, G. (2008). Measuring organizational performance as a dependent variable: Towards methodological best practice. Journal of Management, 35(3), 718-804. https://doi.org/10.1177/0149206308330560

Sangiorgi, D., \& Siboni, B. (2017). The disclosure of intellectual capital in Italian universities: What has been done and what should be done. Journal of Intellectual Capital, 18(2), 354-372. https://doi.org/10.1108/JIC09-2016-0088

Seleim, A., Ashour, A., \& Bontis, N. (2007). Human capital and organizational performance: A study of Egyptian software companies. Management Decision, 45(4), 789-801. https://doi.org/10.1108/00251740710746033

Seleim, A., \& Khalil, O. (2011). Understanding the knowledge management-intellectual capital relationship: A two-way analysis. Journal of Intellectual Capital, 12(4), 586-614. https://doi.org/10.1108/14691931111181742

Shahzad, K., Bajwa, S., Siddiqi, A., Ahmid, F., \& Sultani, A. (2016). Integrating knowledge management (KM) strategies and processes to enhance organizational creativity and performance: An empirical investigation. Journal of Modelling in Management, 11(1), 154-179. https://doi.org/10.1108/JM2-07-2014-0061

Shannak, R., Obeidat, B., \& Masa'deh, R. (2012). Culture and the implementation process of strategic decisions in Jordan. Journal of Management Research, 4(4), 257-281. https://doi.org/10.5296/imr.v4i4.2160

Shariatmadari, M., \& Forouzandeh, B. (2015). The relation between knowledge management and human capital with transformational leadership of educational principals. International Business and Management, 11(1), 5156.

Sivalogathasan, V., \& Wu, X. (2015). Impact of organization motivation on intellectual capital and innovation capability of the textile and apparel industry in Sri Lanka. International Journal of Innovation Science, 7(2), 153168. https://doi.org/10.1260/1757-2223.7.2.153

Stewart, T. A. (1997). Intellectual capital: The new wealth of nations. New York: Doubleday Dell Publishing Group.

Sun, P. (2010). Five critical knowledge management organizational themes. Journal of Knowledge Management, 14(4), 507-523. https://doi.org/10.1108/13673271011059491

Sweis, R., Fallaq, M., Buqjati, J., \& Abu-Hammad, A. (2011). Knowledge management processes and effect on achieving competitive advantages: A case study of Jordan telecom group "Orange”. Dirasat: Administrative Sciences, Jordan University, 7(4), 511-526.

Sytnik, N. I. (2016). Development of knowledge management infrastructure in organization. Marketing and Management of Innovations, 1, 126-136.

Tan, L. P., \& Wong, K. Y. (2015). Linkage between knowledge management and manufacturing performance: A structural equation modeling approach. Journal of Knowledge Management, 19(4), 814-835. https://doi.org/10.1108/JKM-11-2014-0487

Tastan, S., \& Davoudi, S. (2015). A research on the relevance of intellectual capital and employee job performance as measured with distinct constructs of in-role and extra-role behaviors. Indian Journal of Science and Technology, 8(7), 724-734. https://doi.org/10.17485/ijst/2015/v8iS7/71229

Theriou, N., Maditinos, D., \& Theriou, G. (2011). Knowledge management enabler factors and firm performance: An empirical research of the Greek medium and large firms. European Research Studies Journal, 2, 97 134.

Tomislav, H., Bach, M. P., \& Vukšić, V. B. (2012). Influence of strategic approach to BPM on financial and nonfinancial performance. Baltic Journal of Management, 7(4), 376-396. https://doi.org/10.1108/17465261211272148

Tovstiga, G., \& Tulugurova, E. (2009). Intellectual capital practices: A four-region comparative study. Journal of Intellectual Capital, 10(1), 70-80. https://doi.org/10.1108/14691930910922905 
Knowledge Management Process and Organization Performance

Tubigi, M., \& Alshawi, S. (2015). The impact of knowledge management processes on organisational performance: The case of the airline industry. Journal of Enterprise Information Management, 28(2), 167-185. https://doi.org/10.1108/JEIM-01-2014-0003

Uzoma, A. C., Ugwoke, R. O., \& Rita, C. N. (2017). Intellectual capital management and organizational performance in selected food and beverage companies in Nigeria. International Journal of Advanced Scientific Research and Management, 2(1), 47-58.

Valaei, N., Nikhashemi, S. R., \& Javan, N. (2017). Organizational factors and process capabilities in a KM strategy: Toward a unified theory. Journal of Management Development, 36(4), 560-580. https://doi.org/10.1108/JMD-04-2016-0057

Valaei, N., \& Rezaei, S. (2017). Does web 2.0 utilisation lead to knowledge quality, improvisational creativity, compositional creativity, and innovation in small and medium-sized enterprises? A sense-making perspective. Technology Analysis \& Strategic Management, 29(4), 381-394. https://doi.org/10.1080/09537325.2016.1213806

Wang, Z., Wang, N., Cao, J., \& Ye, X. (2016). The impact of intellectual capital-knowledge management strategy fit on firm performance. Management Decision, 54(8), 1861-1885. https://doi.org/10.1108/MD-06-2015$\underline{0231}$

Wang, Z., Wang, N., \& Liang, H. (2014). Knowledge sharing, intellectual capital and firm performance. Management Decision, 52(2), 230-258. https://doi.org/10.1108/MD-02-2013-0064

Wiig, M.K. (1997). Integrating intellectual capital and knowledge management. Long Range Planning, 30(3), 399405. https://doi.org/10.1016/S0024-6301(97)90256-9

Yadav, N. (2013). A role of knowledge management in organizational performance. International Journal of Scientific \& Engineering Research, 4(11), 195-201.

Yaghoubi, N. M., Salarzehi, H., \& Moloudi, J. (2010). Review of relationship between intellectual capital and organizational justice. Asian Social Science, 6(10), 120-126. https://doi.org/10.5539/ass.v6n10p120

Zaied, H., Hussein, G., \& Hassan, M. (2012). The role of knowledge management in enhancing organizational performance. International Journal of Information Engineering and Electronic Business, 5, 27-35. https://doi.org/10.5815/ijieeb.2012.05.04

Zeglat, D., \& Zigan, K. (2014). Intellectual capital and its impact on business performance: Evidences from the Jordanian hotel industry. Tourism and Hospitality Research, 13(2), 83-100. https://doi.org/10.1177/1467358413519468

\section{APPENDICES}

\section{APPENDIX A. FINAL MEASUREMENT ITEMS}

\begin{tabular}{|c|l|}
\hline $\begin{array}{l}\text { Item num- } \\
\text { ber }\end{array}$ & Item statements \\
\hline KP: Knowledge Management Process (KG, KT, KS, \& KA) \\
\hline KG: Knowledge Generation \\
\hline KG1 & The dialogue encourages the employees of the company to exchange ideas. \\
\hline KG2 & The company is keen to attend employees training courses and conferences. \\
\hline KG3 & $\begin{array}{l}\text { The company's management uses the brainstorming method with the staff to par- } \\
\text { ticipate in solving the problems faced by the company. }\end{array}$ \\
\hline KG4 & $\begin{array}{l}\text { Employees are encouraged and motivated to generate creative ideas and offer them } \\
\text { rewards. }\end{array}$ \\
\hline
\end{tabular}




\begin{tabular}{|c|c|}
\hline \multicolumn{2}{|c|}{ KT: Knowledge Storage } \\
\hline KT1 & $\begin{array}{l}\text { Company employees can freely access to documents and knowledge stored the } \\
\text { company. }\end{array}$ \\
\hline KT2 & The company stores knowledge in the knowledge bases. \\
\hline KT3 & $\begin{array}{l}\text { The company documents the previous experiments in handbooks or through its } \\
\text { bases to be applied later. }\end{array}$ \\
\hline \multicolumn{2}{|c|}{ KS: Knowledge Sharing } \\
\hline KS1 & $\begin{array}{l}\text { We promote sharing of information and knowledge between team members and the } \\
\text { various units. }\end{array}$ \\
\hline KS2 & $\begin{array}{l}\text { Our company uses mechanisms and means for knowledge exchange across individ- } \\
\text { uals, groups and organizational levels. }\end{array}$ \\
\hline KS3 & Employees in our company frequently share knowledge based on their experience. \\
\hline KS4 & $\begin{array}{l}\text { Employees in our company frequently share reports and official documents that } \\
\text { they prepare by themselves with members of my company. }\end{array}$ \\
\hline \multicolumn{2}{|c|}{ KA: Knowledge Application } \\
\hline KA1 & $\begin{array}{l}\text { The company's staff always know where they can find experiences and knowledge } \\
\text { they need. }\end{array}$ \\
\hline KA2 & Knowledge bases help in solving problems related to work. \\
\hline KA3 & The staff feels that the knowledge is available with a complete freedom to apply it. \\
\hline KA4 & $\begin{array}{l}\text { The company is able to utilize knowledge for improving work effectiveness and fi- } \\
\text { ne-tuning strategic vision. }\end{array}$ \\
\hline \multicolumn{2}{|c|}{ KI: Knowledge Management Infrastructure (OC, IT, \& ST) } \\
\hline \multicolumn{2}{|c|}{ OC: Organizational Culture } \\
\hline OC1 & $\begin{array}{l}\text { Employees in our company understand the importance of knowledge sharing to } \\
\text { corporate success. }\end{array}$ \\
\hline OC2 & $\begin{array}{l}\text { Employees in our company are encouraged to participate in seminars and group } \\
\text { discussion. }\end{array}$ \\
\hline OC3 & Employees in our company are generally trust worthy. \\
\hline OC4 & Employees in our company are willing to support and help each other. \\
\hline \multicolumn{2}{|c|}{ IT: IT Infrastructure } \\
\hline IT1 & $\begin{array}{l}\text { The company has invested in effective knowledge management technologies to ena- } \\
\text { ble knowledge sharing between employees (e.g. intranets/ extranets, groupware, re- } \\
\text { positories, etc.). }\end{array}$ \\
\hline IT2 & Information technology plays a critical role in facilitating knowledge sharing. \\
\hline IT3 & $\begin{array}{l}\text { Our company has technological systems that help us communicate outside and in- } \\
\text { side the organization. }\end{array}$ \\
\hline IT4 & $\begin{array}{l}\text { Our company uses technology that allows us as a learning group from several } \\
\text { sources at different times. }\end{array}$ \\
\hline
\end{tabular}




\begin{tabular}{|c|c|}
\hline \multicolumn{2}{|c|}{ OS: Organizational Structure } \\
\hline OS1 & Organizational structure is flat(Few management levels). \\
\hline OS2 & Structure facilitates interaction between individuals and exchange of knowledge. \\
\hline OS3 & Decision making is decentralized. \\
\hline OS4 & The organizational structure facilitates knowledge discovery and creation. \\
\hline \multicolumn{2}{|c|}{ IC: Intellectual Capital (HC, SC, \& RC) } \\
\hline \multicolumn{2}{|c|}{ HC: Human Capital } \\
\hline HC1 & Our company employees are highly skilled. \\
\hline HC2 & Our company employees are creative and bright. \\
\hline HC3 & $\begin{array}{l}\text { The employees of our company have the ability to develop new ideas and } \\
\text { knowledge. }\end{array}$ \\
\hline $\mathrm{HC} 4$ & The company's employees have high experience in their jobs. \\
\hline \multicolumn{2}{|c|}{ SC: Structural Capital } \\
\hline SC1 & Our company has an easily-accessible information system. \\
\hline SC2 & Our company invests a high proportion of its money in patent maintenance. \\
\hline SC3 & Transaction end time is very low. \\
\hline SC4 & Organization is a bureaucratic nightmare. \\
\hline \multicolumn{2}{|c|}{ RC: Relational Capital } \\
\hline $\mathrm{RC1}$ & $\begin{array}{l}\text { Our company was informed by the opinions and suggestions of its customers, lis- } \\
\text { tening to them and solving their problems. }\end{array}$ \\
\hline RC2 & $\begin{array}{l}\text { Our company is interested in achieving the satisfaction and loyalty of customers and } \\
\text { maintains good relations with them. }\end{array}$ \\
\hline RC3 & The company has a complete database about suppliers constantly updated. \\
\hline RC4 & Our company is confident of future with customer. \\
\hline \multicolumn{2}{|c|}{ OP: Organization Performance (NP \& FP) } \\
\hline \multicolumn{2}{|c|}{ FP: Financial Performance } \\
\hline FP1 & Return on investment of our company is better than that of key competitors. \\
\hline FP2 & Average profitability of our company is better than that of key competitors. \\
\hline FP3 & Profit growth of our company is better than that of key competitors. \\
\hline FP4 & Sales growth of our company is better than that of key competitors. \\
\hline \multicolumn{2}{|c|}{ NP: Non Financial Performance } \\
\hline NP1 & Reputation of our company from the point of view of customers has improved. \\
\hline NP2 & Cost management of our company is better than that of key competitors. \\
\hline NP3 & Customer satisfaction of our company is better than that of key competitors. \\
\hline NP4 & Quality development of our company is better than that of key competitors. \\
\hline
\end{tabular}


APPENDIX B. RELIABILITY AND VALIDITY OF THE CONSTRUCTS

\begin{tabular}{|c|c|c|c|c|c|}
\hline Construct & $\begin{array}{c}\text { Item } \\
\text { num- } \\
\text { ber }\end{array}$ & $\begin{array}{c}\text { Loadings } \\
\text { EFA }\end{array}$ & $\begin{array}{c}\text { Loadings } \\
\text { CFA }\end{array}$ & $\begin{array}{c}\text { Cronbach's } \\
\text { Alpha }\end{array}$ & $\begin{array}{c}\text { Composite } \\
\text { reliability }\end{array}$ \\
\hline \multirow[t]{5}{*}{ Knowledge Generation (KG) } & & & & 0.903 & 0.852 \\
\hline & KG1 & 0.695 & 0.768 & & \\
\hline & KG2 & 0.651 & 0.743 & & \\
\hline & KG3 & 0.605 & 0.718 & & \\
\hline & KG4 & 0.609 & 0.817 & & \\
\hline \multirow[t]{4}{*}{ Knowledge Storage (KT) } & & & & 0.696 & 0.841 \\
\hline & KT1 & 0.723 & 0.756 & & \\
\hline & KT2 & 0.632 & 0.766 & & \\
\hline & KT3 & 0.674 & 0.665 & & \\
\hline \multirow[t]{5}{*}{ Knowledge Sharing (KS) } & & & & 0.922 & 0.812 \\
\hline & KS1 & 0.701 & 0.738 & & \\
\hline & KS2 & 0.704 & 0.822 & & \\
\hline & KS3 & 0.761 & 0.828 & & \\
\hline & KS4 & 0.713 & 0.814 & & \\
\hline \multirow[t]{5}{*}{ Knowledge Application (KA) } & & & & 0.764 & 0.881 \\
\hline & KA1 & 0.598 & 0.653 & & \\
\hline & KA2 & 0.602 & 0.637 & & \\
\hline & KA3 & 0.598 & 0.767 & & \\
\hline & KA4 & 0.572 & 0.658 & & \\
\hline \multirow[t]{5}{*}{ Organizational Culture $(\mathrm{OC})$} & & & & 0.704 & 0.875 \\
\hline & OC1 & 0.611 & 0.622 & & \\
\hline & OC2 & 0.651 & 0.804 & & \\
\hline & OC3 & 0.625 & 0.827 & & \\
\hline & OC4 & 0.569 & 0.840 & & \\
\hline \multirow[t]{5}{*}{ IT Infrastructure (IT) } & & & & 0.702 & 0.824 \\
\hline & IT1 & 0.668 & 0.725 & & \\
\hline & IT2 & 0.698 & 0.770 & & \\
\hline & IT3 & 0.651 & 0.767 & & \\
\hline & IT4 & 0.663 & 0.758 & & \\
\hline
\end{tabular}


Knowledge Management Process and Organization Performance

\begin{tabular}{|c|c|c|c|c|c|}
\hline \multirow[t]{5}{*}{ Organizational Structure (OS) } & & & & 0.688 & 0.819 \\
\hline & OS1 & 0.638 & 0.689 & & \\
\hline & OS2 & 0.641 & 0.830 & & \\
\hline & OS3 & 0.691 & 0.806 & & \\
\hline & OS4 & 0.598 & 0.720 & & \\
\hline \multirow[t]{5}{*}{ Human Capital (HC) } & & & & 0.776 & 0.786 \\
\hline & HC1 & 0.689 & 0.760 & & \\
\hline & $\mathrm{HC} 2$ & 0.661 & 0.743 & & \\
\hline & $\mathrm{HC} 3$ & 0.569 & 0.807 & & \\
\hline & $\mathrm{HC} 4$ & 0.527 & 0.812 & & \\
\hline \multirow[t]{5}{*}{ Structural Capital (SC) } & & & & 0.865 & 0.817 \\
\hline & SC1 & 0.699 & 0.743 & & \\
\hline & SC2 & 0.616 & 0.828 & & \\
\hline & SC3 & 0.621 & 0.769 & & \\
\hline & SC4 & 0.663 & 0.797 & & \\
\hline \multirow[t]{5}{*}{ Relational Capital (RC) } & & & & 0.765 & 0.914 \\
\hline & $\mathrm{RC1}$ & 0.671 & 0.752 & & \\
\hline & RC2 & 0.591 & 0.678 & & \\
\hline & RC3 & 0.606 & 0.841 & & \\
\hline & RC4 & 0.629 & 0.834 & & \\
\hline \multirow{5}{*}{$\begin{array}{l}\text { Non Financial Performance } \\
\text { (NP) }\end{array}$} & & & & 0.814 & 0.894 \\
\hline & NP1 & 0.713 & 0.775 & & \\
\hline & NP2 & 0.773 & 0.888 & & \\
\hline & NP3 & 0.738 & 0.868 & & \\
\hline & NP4 & 0.756 & 0.857 & & \\
\hline \multirow[t]{5}{*}{ Financial Performance (FP) } & & & & 0.824 & 0.859 \\
\hline & FP1 & 0.797 & 0.811 & & \\
\hline & FP2 & 0.728 & 0.824 & & \\
\hline & FP3 & 0.748 & 0.884 & & \\
\hline & FP4 & 0.778 & 0.824 & & \\
\hline
\end{tabular}




\section{BIOGRAPHIES}

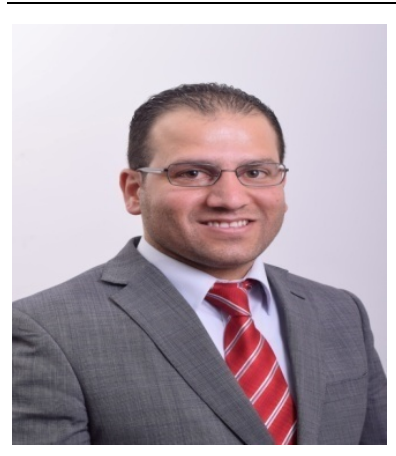

Shadi Habis Abualoush is an Assistant Professor of Business Administration/ Management Information Systems in the Faculty of Administrative Science and Finance at Irbid National University. He gained his $\mathrm{PhD}$ from Jenan University of Lebanon in 2014. His research interests include Information Systems, and Knowledge Management. His research has been accepted by or appeared in such journals as Academy of Taiwan Business Management Review, International Journal of Business Administration, VINE Journal of Information and Knowledge Management Systems, International Journal of Learning and Intellectual Capital, and European Scientific Journal.

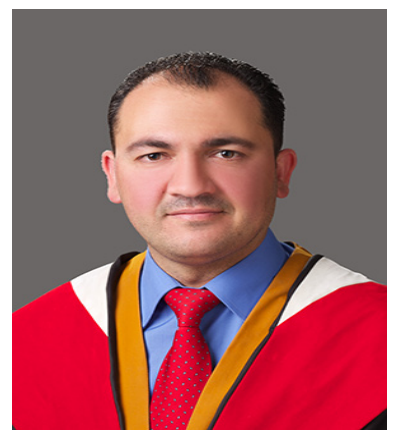

Ra'ed Masa'deh is an Associate Professor of Management Information Systems at the University of Jordan. He received his Ph.D. from the University of Nottingham, UK. Previously, he earned a BS.c degree in Accounting from AL al-Bayt University, Jordan; and MS.c in Finance and Accounting from Brunel University, London, UK. His research interests include Knowledge Economy, IT-Business Strategic Alignment, Information Management, Knowledge Management Capabilities; IT-based Competitive Advantages; Quantitative Methods, and Structural Equation Modeling. His research has been published in journals including Journal of Enterprise Information Management, VINE Journal of Information and Knowledge Management Systems, Journal of Hospitality and Tourism Technology, Journal of Management Development, International Journal of Technology Diffusion, Benchmarking: An International Journal, International Journal of Knowledge Management Studies, International Journal of Business Innovation and Research, Management Research Review.

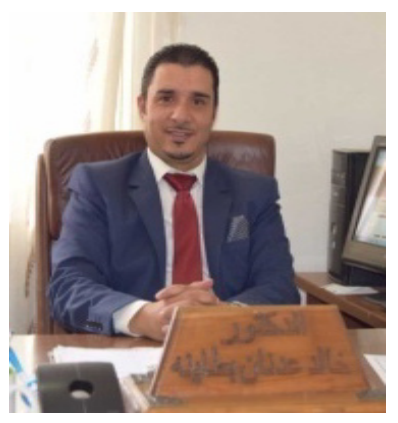

Khaled Adnan Bataineh is an Assistant Professor of Business Administration in the Faculty of Administrative Science and Finance at Irbid National University. He gained his PhD from Jenan University of Lebanon in 2014. His research interests contain Information Systems, and Knowledge Management. His research has been accepted by or appeared in such journals International Journal of Business Administration, International Journal of Learning and Intellectual Capital, and European Scientific Journal.

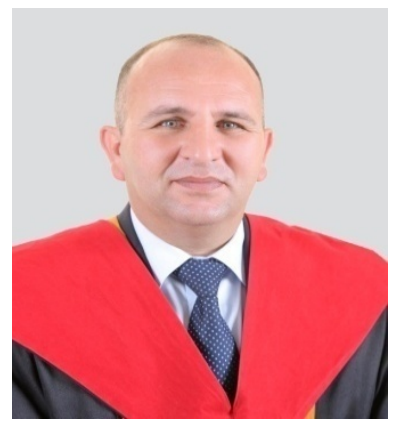

Ala'aldin Alrowwad is an Assistant Professor and Head of the Department of Business Management, School of Business at The University of Jordan, Aqaba Branch, Jordan; and Head of Training Department at the Center of Consultations at The University of Jordan, Aqaba. He received the Ph.D. degree from Arab University for Graduate Studies, Jordan in 2013. His research interests include Management and Organization Behavior, Knowledge Management, and Quantitative Methods. His research has been published in journals including International Business Research, Asian Social Science, Journal of Management Research, and International Journal of Marketing Studies. 